University of South Carolina

Scholar Commons

$10-2004$

\title{
The Dynamics of Market Entry: The Effects of Mergers and Acquisitions on Entry in the Banking Industry
}

\author{
Allen N. Berger \\ University of South Carolina - Columbia, aberger@moore.sc.edu \\ Seth D. Bonime \\ Lawrence G. Goldberg \\ Lawrence J. White
}

Follow this and additional works at: https://scholarcommons.sc.edu/fin_facpub

Part of the Finance and Financial Management Commons

\begin{abstract}
Publication Info
Published in Journal of Business, Volume 77, Issue 4, 2004, pages 797-834.

http://www.jstor.org/action/showPublication?journalCode=jbusiness

(c) 2004 The University of Chicago Press
\end{abstract}

This Article is brought to you by the Finance Department at Scholar Commons. It has been accepted for inclusion in Faculty Publications by an authorized administrator of Scholar Commons. For more information, please contact digres@mailbox.sc.edu. 


\section{Lawrence G. Goldberg}

Department of Finance, University of Miami

\section{Lawrence J. White}

Stern School of Business, New York University

\section{The Dynamics of Market Entry: The Effects of Mergers and Acquisitions on Entry in the Banking Industry*}

\section{Introduction}

Entry, or the credible threat of entry, is important in many aspects of industrial organization, from theory to empirical research to institutional

* The opinions expressed do not necessarily reflect those of the Board of Governors or its staff, or of McKinsey \& Company (Seth Bonime contributed to this paper prior to joining Pepsi). We also thank John Boyd, Philipp Hartmann, Chris James, and Ken Carow for excellent discussant comments; Bob Avery, Sally Davies, Tim Critchfield, Bob DeYoung, Luke Froeb, Al Gilbert, Steve Seelig, Phil Strahan, Greg Werden, and the participants at the Allied Social Sciences Association meetings; the Chicago Federal Reserve Conference on Bank Structure and Competition, Financial Management Association meetings, the Southern Finance Association meetings, the Center for Financial Studies/Wharton Financial Institutions Center conference on "Competition among Banks: Good or Bad?" and the Federal Reserve Bank of New York seminar for helpful comments; and Kelly Bryant and Nate Miller for outstanding research assistance.

(Journal of Business, 2004, vol. 77, no. 4)

(C) 2004 by The University of Chicago. All rights reserved. 0021-9398/2004/7704-0006\$10.00
We study the dynamics of market entry following mergers and acquisitions (M\&As) using banking industry data. The findings suggest that M\&As are associated with statistically and economically significant increases in the probability of entry. The data suggest that M\&As affect the proportion of the markets with entry by about $10-20 \%$. These findings also suggest that entry may, be part of an "external" effect of M\&As that helps supply credit to some relationshipdependent small business borrowers. Our results are robust to the use of alternative econometric methods, changes in specifications of the exogenous variables, and alteration of the data samples. 
practice. All these aspects share a concern that participants in concentrated markets may not behave in a competitive, socially efficient fashion unless there is active market entry to keep them "honest." The theory has generated a number of factors that should be important to market entry, the empirical literature has tested some of these hypothesized factors, and antitrust authorities have weighed these factors in their approval/denial processes.

The theories and tests of market entry to date have focused primarily on factors such as profitability, concentration, and growth of the market, which may proxy the prospects of future abnormal profits and invite entry. There has been little dynamic analysis of entry in response to the activities of the incumbent market participants, and, in particular, there has been little analysis of the effects of mergers and acquisitions (M\&As) on subsequent entry. This is surprising, given the important role that M\&As play in changing the structure and competitive conditions in a market, and the role that future entry prospects in response to M\&As play in antitrust analysis.

The commercial banking industry provides an almost ideal laboratory for analyzing these issues. Banks produce relatively homogeneous products in a large number of geographically segmented markets of various sizes, with different M\&A experiences, and other variations in market structure and economic conditions. We examine entry activity in over 2,700 local banking markets-metropolitan statistical areas (MSAs) or non-MSA counties across the United States - during a period of 19 years from 1980 to 1998, for a total of over 52,000 market-year observations and almost 4,000 actual market entries. We are able to trace the effects of over 10,000 bank M\&As over the time period and distinguish among several types of consolidation. This contrasts well with most other studies of entry, which typically have many fewer observations, often use four-digit SIC categories that represent much more heterogeneous products and services, and generally do not have information on M\&A activity.

The banking data also allow us to examine the effects of regulatory differences on the probability of de novo entry. Over our sample period, a number of states had unit banking laws and other regulations that restricted existing banks from expanding into new local markets. We hypothesize that these geographic restrictions on competition create local market power, which, in turn, may increase the probability of de novo entry. That is, barriers to one type of local market entry (branching by existing banks in other markets) may create incentives and opportunities for another type of entry (de novo entry by banks with new charters).

The issue of entry into local banking markets in response to bank M\&As raises policy concerns as well as being an interesting research question. Whether or not there is new entry after consolidation activity 
has important implications for antitrust policy and the efficiency of banking markets. An additional policy issue concerns the adequate supply of funds to bank-dependent small businesses. The extant research discussed here suggests that the consolidation of the banking industry results in substantially reduced small business lending by banks that engage in M\&A activity but that there may be an "external" effect of M\&As in which other lenders in the same local markets make up for some of this reduced supply. New entrants may be part of this "external" effect.

Although the amount of lending by de novo entrants is small relative to the total lending of the banking industry, recent research discussed here suggests that these entrants may provide substantial external effects in response to M\&As in terms of small business lending in their local markets. This research suggests that small banks devote much higher proportions of their assets to small business loans than the large banks typically involved in M\&As, and de novo entrants have even higher ratios of small business loans to assets than other small banks. Thus, the relatively high small business lending of recent entrants can make up for a substantial portion of any reduced supply of small business loans from consolidation in a local market. To illustrate, one recent study (Berger, Goldberg, and White 2001) found that the average ratio of small business loans to assets was $13.64 \%$ for "young" small banks (age $\leq 5$ years, assets $\leq \$ 100$ million), $7.55 \%$ for "mature" small banks (age $>20$ years, assets $\leq \$ 100$ million), and $2.95 \%$ for very large banks (all ages, assets $>\$ 10$ billion). Based on these data, if a very large bank were to merge with a "mature" small bank that has $\$ 100$ million in assets and it were to apply the large bank's lending policies to the consolidated bank, its small business loans would decrease by $\$ 4.6$ million $([0.0755-0.0295] \times \$ 100$ million $)$. A single de novo entrant with just $\$ 33.72$ million in assets [\$4.6 million/0.1364] could replace this entire decrease in lending. This recent study also found that the additional competition of a de novo entrant may stimulate small business lending by other small banks in the local market. As well, the threat of new entry may result in the consolidating banks and other market incumbents increasing their supplies of small business credit in anticipation of possible entry.

We address these research and policy issues in this paper. We estimate a dynamic empirical model of entry into local banking markets that includes M\&A activity and other market factors. The findings suggest that bank M\&As are associated with statistically and economically significant increases in the probability of subsequent entry into the same local markets. We also ensure that the findings are robust by subjecting them to robustness checks that (1) use alternative econometric methods, (2) change the specifications of the dependent and exogenous variables, and (3) alter the data samples. 
The remainder of the paper is organized as follows. Section 2 reviews the relevant literature on entry in general and in the banking industry in particular. Section 3 describes the empirical literature on the effects of bank M\&As on market power, efficiency, and the supply of small business credit by banks in the market, effects that may help determine the probability of market entry. Section 4 gives some facts about de novo entry in banking that help guide the empirical analysis. Section 5 discusses the hypotheses, methodology, and variables employed in the analysis. Section 6 summarizes the empirical results, and Section 7 concludes.

\section{Prior Evidence on Entry}

In this section, we first discuss the empirical evidence on entry in general, then turn to evidence on entry in the banking industry. Section 3 reviews the empirical literature on the effects of bank M\&As, which may help determine the probability of entry in the local banking markets.

\section{A. The General Entry Literature}

Theory, beginning at least with Bain (1956) and Sylos-Labini (1962), predicts entry when there are strong prospects for future abnormal profits. The empirical literature has concentrated primarily on factors such as profitability, concentration, and growth to serve as proxies for expected future abnormal profits from entry. The dynamic effects of M\&As are generally not considered in the empirical literature.

Siegfried and Evans (1994) summarized the empirical work on entry across industries, in both the United States and other countries. ${ }^{1}$ They found that entry is positively related to industry profitability and growth. Earlier empirical research by Siegfried and Evans (1992) found that entry rates and exit rates are positively correlated. They interpreted exit, however, as firms' responses to declining prospects, as would occur when a firm is liquidated or acquired by another firm after a string of losses. They did not address the possibility that M\&As (as a form of exit) occur in good times as well as bad.

Another review by Geroski (1995) found that de novo entry is common across industries, but entrants appear to have short life spans. The survival rate of entrants is low, and it takes more than a decade to achieve the size of the average incumbent when entrants do survive. Entry rates vary more within industries than across industries. Even

1. Important studies of non-U.S. industries include Orr (1974), Baldwin and Gorecki (1991), Morch von der Fehr (1991), and Mata (1993). 
though there is substantial entry, econometric estimates indicate that entry barriers are high. Entry reacts slowly to high profits, and it is difficult to estimate entry rates using measures of profitability and entry barriers.

Further, the ex post economic effects of entry do not follow theoretical expectations as closely as would be expected. Entry has only modest effects on average price-cost margins. Incumbent response to entry is selective. Pricing is not usually used to block entry, although marketing efforts are used for this purpose. Most of the literature examines short-term effects of entry rather than long-term effects, so it is not surprising to find that entry does not greatly affect profitability. Entry does appear to be associated with high rates of innovation and increases in efficiency. Geroski (1995) concluded that the procompetitive effects of entry may be exaggerated and that active rivalry among existing firms in the market is preferable to entry since entry is often too slow, too small in scale, and too erratic to have substantial effects.

There are distinct advantages to examining regulated industries. The government mandates substantial data requirements of regulated firms. Also, many of these regulated markets are local, allowing the researcher to segment the regulated industry into geographic markets, thus permitting more extensive analysis of the industry. In addition to banking, entry studies have been performed on one other regulated industry, airlines.

For the airline industry, Joskow, Werden, and Johnson (1994) found that entry and exit have important competitive effects, contrary to the interindustry findings. They found that, although entry is generally not induced by above-normal price levels on a city-pair basis, entry reduces fares and increases output, while exit increases fares and reduces output. In addition, incumbents cut price and maintain output in response to entry, whereas survivors increase both price and output in response to exit.

Thus, the findings from the literature outside of banking as a whole cast doubt on the ability of entry to restrain anticompetitive behavior and are consistent with a continued need for antitrust restraint on M\&As. Essentially, the findings suggest that entry frequently does not occur to curb the exercise of market power. Moreover, although entry may "work" in terms of lowering prices when it does occur, the effect may be short-lived because of the low survival rate.

\section{B. The Bank Entry Literature}

The most relevant entry evidence for our study comes from research on the banking industry. More detailed data are available for banking than any other industry, and the results of these studies are more in line 
with theoretical models of market behavior. We focus on several recent studies here. ${ }^{2}$

Amel and Liang (1997) estimated a two-equation model of entry and profits for 1977-1988. Their results support the existence of a competitive process in banking markets: New entrants were attracted by high profits, market size, and market growth. ${ }^{3}$ They also found that entry reduces market power in pricing.

Moore and Skelton (1998) examined the paradox of the recent increase in de novo bank entry, given the decrease in the total number of banking organizations at the same time. Most of the analysis covers the year 1997. They found that de novo banks organize to take advantage of local conditions favoring entry, such as high growth and deficiencies in the provision of certain services (e.g., small business lending). The authors concluded that new banks increased the level of competition in some markets.

Finally, some recent research confirms our findings of a strong positive effect of M\&As on subsequent de novo entry in the same local markets. Seelig and Critchfield (2002) examined the determinants of entry in banking in MSAs over 1995 to1997 and originally found a significant negative relationship between mergers and de novo entry. However, those results were due to a programming error. In their updated paper, they corrected the error, added data from 1998, and made other changes; their findings are now reversed and consistent with ours. ${ }^{4}$

\section{Prior Evidence on the Effects of Bank M\&As}

Despite very little direct empirical evidence on the effects of bank M\&As on subsequent entry, there is substantial evidence on other effects of M\&As that may influence entry decisions. M\&As can affect the probability of de novo entry in the same local market in at least three ways. First, M\&As may affect the exercise of market power in setting prices. The probability of entry should vary directly with the change in market power. Second, M\&As may change the efficiency of the M\&A participants or other local competitors. The probability of entry should vary inversely with the change in efficiency, as more efficient incumbents may be stronger future competitors. Third,

2. See also Rhoades (1997) for an extensive discussion of the barriers to entry in banking.

3. Amel and Liang define entry by either de novo charters by new banks or new branch offices by existing banks from other markets. In contrast, we focus exclusively on de novo charters.

4. A Federal Reserve Bank of Kansas City Economic Review article (Keeton 2000) reviewed both an earlier version of our paper and the original Seelig and Critchfield working paper and did some additional analysis that also supports our finding that M\&As tend to increase the probability of subsequent entry into banking markets. 
M\&As may affect the supply of small business credit in the local market. The probability of entry should vary directly with the degree to which institutions participating in M\&As reduce their supply of this credit.

We characterize the studies of M\&As as either static or dynamic analyses. Static analyses examine the effects of changes in bank characteristics associated with M\&As, such as increased size or market concentration. Dynamic analyses compare the data for banks after M\&As with pre-M\&A data or with data on other banks that have not recently engaged in M\&As. Dynamic analyses incorporate the possibility that M\&As may involve changes in organizational focus, differences in managerial behavior, or disruptions from consummating M\&As as well as the static effects. A comprehensive survey of the consequences of bank M\&As is found in Berger, Demsetz, and Strahan (1999). We highlight those findings, and review newer studies not referenced in that survey.

\section{A. Bank M\&As and Market Power}

M\&As between banks with significant local market overlap ex ante may increase local market concentration and allow the consolidated bank and other banks in the local market to raise profits by setting prices less favorable to customers. This may affect rates and fees on small business loans and small deposits, as these products are generally competed for on a local basis. M\&As of the market-extension type that join banks in different local markets are less likely to increase local market power. The static literature on the effects of local market concentration generally found that banks in more concentrated markets charge higher rates on small business loans and pay lower rates on small deposits and that their deposit rates were "sticky" or slow to respond to changes in open-market interest rates, consistent with the exercise of market power.

Dynamic studies of the effects of bank M\&As on prices have yielded mixed results as to the overall importance of M\&As to the prices charged by M\&A participants and their local market rivals. However, for in-market M\&As with significant market overlap, there are strong effects on deposit prices. Thus, at least some types of M\&As appear to boost the exercise of market power in pricing, which may increase the probability of entry. ${ }^{5}$

5. Note that potential M\&As that would result in large increases in concentration and market power may not actually occur. Antitrust authorities often block, alter, or deter M\&As that are expected to result in substantial increases in market power. Such M\&As may also be deterred by the prospects of entry, which may raise output or lower prices so as to eliminate most of the private gains to these M\&As (Werden and Froeb 1998). 


\section{B. Bank M\&As and Efficiency}

M\&As may affect the scale, scope, or product mix efficiency by moving the banks to a different output vector. M\&As may also change $X$-efficiency if the consolidated bank alters its organizational focus or managerial behavior or suffers disruptions from consummating the M\&A. Banks may also improve their efficiency, broadly defined, by diversifying their portfolios and improving their risk-expected return trade-offs.

Static studies of the scale, scope, and product mix efficiencies using 1980s data generally suggest little or no cost-efficiency improvement from the change in the output vector, although recent research suggests that the scale economies may have increased in the 1990s. The size and geographic spread of interstate banking organizations also appears to improve the risk-expected return trade-offs for many of these banks, increasing efficiency, broadly defined.

Dynamic studies of the $X$-efficiency effects of bank M\&As generally have found very little or no cost-efficiency improvement (see also Kim and White 2001). However, studies of the profit-efficiency effects found that M\&As improved profit efficiency and this improvement could be linked to improved diversification of risks. Therefore, the evidence generally suggests that M\&As may improve the efficiency of the M\&A participants somewhat on average, which may deter de novo entry.

\section{Bank M\&As and Small Business Lending}

Bank M\&As may reduce the supply of credit to some relationshipdependent small business borrowers as the consolidated banks at least partially exit from this niche of the market. This may occur because the larger, more organizationally complex banks created by M\&As may encounter organizational diseconomies from providing relationshipbased loans along with the transactions-based loans in which these banks tend to specialize. This may also occur because of difficulties in transmitting the type of "soft" information that relationship lending often requires through the communication channels of large organizations (Stein 2002). It is also possible that short-term disruptions caused by the consolidation process itself may give other banks, either local incumbents or new entrants, the opportunity to take away customers who perceive a reduction in service quality or availability.

Supporting these arguments, static studies found that larger banks devote a lesser proportion of their assets to small business lending than do smaller institutions. Some evidence also suggests that, specifically, relationship-dependent small borrowers tend to receive less credit from large banks. A number of dynamic studies examined the 
effects of U.S. bank M\&As on small business lending. A common finding is that M\&As in which one or more of the banking organizations is large tend to reduce small business lending, although there are exceptions.

As noted previously, some research also found that there may be a dynamic "external" effect of M\&As, in which other lenders make up for some of the reduced supply by banks that engage in M\&As (see also Berger, Goldberg, and White 2001; Avery and Samolyk 2004). De novo entry could be an important component of this external effect if M\&As increase the probability of new entry. This could yield a relatively large effect, as discussed already, since recent de novo entrants tend to have relatively high small business loan ratios.

Importantly, the research often found that both the direct effects and external effects of consolidation differed by the type of M\&A. In particular, mergers (consolidations of bank charters) had different effects from acquisitions (banks retaining their charters but changing their top-tier bank-holding-company ownership).

\section{Some Facts about De Novo Entry}

This section presents some statistics about de novo entry in U.S. banking and some of the factors associated with this entry. These data suggest some potentially important determinants of entry that are incorporated in our multivariate empirical analysis.

Table 1 reports statistics on the annual frequency of de novo entry into local U.S. banking markets (defined as metropolitan statistical areas or non-MSA counties) over the period 1980-1998. As shown in the bottom row of Part A of the table, there were 52,598 total market-years, or 19 years times an average of 2,768 local markets in each year. ${ }^{6}$ The bottom row also shows that 50,383 times or $95.79 \%$ of the time no new banks entered the market. Although entry occurred only $4.21 \%$ of the time, this still represents a tremendous amount of entry, with 3,875 total entries or 7.37 entries per 100 local markets per year. A number of markets had many entrants in the same year. On 124 separate occasions, 5 or more banks entered the same market in the same year, with a maximum of 40 banks (in Houston in 1983).

The data in Panel A suggest that market size is a strong positive determinant of the probability of entry and number of entrants. The

6. Although these market definitions are imperfect, there is considerable research evidence supporting these local geographic demarcations as the markets for retail banking products such as small business loans and retail deposits. Survey data indicate that small businesses and households almost always choose a local financial institution (Kwast, Starr-McCluer, and Wolken 1997), whereas corporate customers may shop for wholesale financial services in national or international markets. 


\begin{tabular}{|c|c|c|c|c|c|c|c|c|c|c|c|c|c|}
\hline \multirow{2}{*}{$\begin{array}{l}\text { Market Size } \\
\text { (deposits) }\end{array}$} & \multicolumn{9}{|c|}{ Number and Percent of Market Years with Various Numbers of Entrants } & \multirow{2}{*}{$\begin{array}{l}\text { Maximum } \\
\text { \# Entrants }\end{array}$} & \multirow{2}{*}{$\begin{array}{c}\text { Entrants/100 } \\
\text { Mkt Years }\end{array}$} & \multirow{2}{*}{$\begin{array}{c}\text { Total } \\
\text { \# Entrants }\end{array}$} & \multirow{2}{*}{$\begin{array}{c}\text { Total } \\
\text { Mkt Years }\end{array}$} \\
\hline & 0 & 1 & 2 & 3 & 4 & 5 & $6-10$ & $11-20$ & $21+$ & & & & \\
\hline \multicolumn{14}{|c|}{ Panel A: All Markets } \\
\hline \multirow[t]{2}{*}{$<\$ 100 \mathrm{M}$} & 18319 & 152 & 3 & & & & & & & 2 & 0.86 & 158 & 18474 \\
\hline & $99.16 \%$ & $0.82 \%$ & $0.02 \%$ & & & & & & & & & & $100.00 \%$ \\
\hline \multirow{2}{*}{$\$ 100-300 \mathrm{M}$} & 19545 & 361 & 9 & & & & & & & 2 & 1.90 & 379 & 19915 \\
\hline & $98.14 \%$ & $1.81 \%$ & $0.05 \%$ & & & & & & & & & & $100.00 \%$ \\
\hline \multirow[t]{2}{*}{$\$ 300 M-\$ 1 B$} & 9067 & 377 & 40 & 3 & 1 & & & & & 4 & 4.95 & 470 & 9488 \\
\hline & $95.56 \%$ & $3.97 \%$ & $0.42 \%$ & $0.03 \%$ & $0.01 \%$ & & & & & & & & $100.00 \%$ \\
\hline \multirow{2}{*}{$\$ 1-5 B$} & 2808 & 468 & 87 & 23 & 6 & 2 & 3 & 1 & & 11 & 22.78 & 774 & 3398 \\
\hline & $82.64 \%$ & $13.77 \%$ & $2.56 \%$ & $0.68 \%$ & $0.18 \%$ & $0.06 \%$ & $0.09 \%$ & $0.03 \%$ & & & & & $100.00 \%$ \\
\hline \multirow[t]{2}{*}{$>\$ 5 B$} & 644 & 307 & 132 & 80 & 42 & 27 & 58 & 24 & 9 & 40 & 158.28 & 2094 & 1323 \\
\hline & $48.68 \%$ & $23.20 \%$ & $9.98 \%$ & $6.05 \%$ & $3.17 \%$ & $2.04 \%$ & $4.38 \%$ & $1.81 \%$ & $0.68 \%$ & & & & $100.00 \%$ \\
\hline \multirow{3}{*}{ TOTAL } & 50383 & 1665 & 271 & 106 & 49 & 29 & 61 & 25 & 9 & 40 & 7.37 & 3875 & 52598 \\
\hline & $95.79 \%$ & $3.17 \%$ & $0.52 \%$ & $0.20 \%$ & $0.09 \%$ & $0.06 \%$ & $0.12 \%$ & $0.05 \%$ & $0.02 \%$ & & & & $100.00 \%$ \\
\hline & \multicolumn{9}{|c|}{ Panel B: Metropolitan Markets } & & & & \\
\hline$<\$ 100 \mathrm{M}$ & $\begin{array}{r}3 \\
100.00 \%\end{array}$ & & & & & & & & & 0 & 0.00 & 0 & 3 \\
\hline \multirow[t]{2}{*}{$\$ 100-300 \mathrm{M}$} & 12 & 2 & & & & & & & & 1 & 14.29 & 2 & 14 \\
\hline & $85.71 \%$ & $14.29 \%$ & & & & & & & & & & & $100.00 \%$ \\
\hline \multirow[t]{2}{*}{$\$ 300 \mathrm{M}-\$ 1 \mathrm{~B}$} & 1398 & 113 & 21 & 2 & & & & & & 3 & 10.50 & 161 & 1534 \\
\hline & $91.13 \%$ & $7.37 \%$ & $1.37 \%$ & $0.13 \%$ & & & & & & & & & $100.00 \%$ \\
\hline \multirow[t]{2}{*}{$\$ 1-5 B$} & 2598 & 454 & 83 & 23 & 6 & 2 & 3 & 1 & & 11 & 23.72 & 752 & 3170 \\
\hline & $81.96 \%$ & $14.32 \%$ & $2.62 \%$ & $0.73 \%$ & $0.19 \%$ & $0.06 \%$ & $0.09 \%$ & $0.03 \%$ & & & & & $100.00 \%$ \\
\hline \multirow[t]{2}{*}{$>\$ 5 B$} & 643 & 306 & 132 & 80 & 42 & 27 & 58 & 24 & 9 & 40 & 158.44 & 2093 & 1321 \\
\hline & $48.68 \%$ & $23.16 \%$ & $9.99 \%$ & $6.06 \%$ & $3.18 \%$ & $2.04 \%$ & $4.39 \%$ & $1.82 \%$ & $0.68 \%$ & & & & $100.00 \%$ \\
\hline \multirow[t]{2}{*}{ TOTAL } & 4654 & 875 & 236 & 105 & 48 & 29 & 61 & 25 & 9 & 40 & 49.78 & 3008 & 6042 \\
\hline & $77.03 \%$ & $14.41 \%$ & $3.91 \%$ & $1.74 \%$ & $0.79 \%$ & $0.48 \%$ & $1.01 \%$ & $0.41 \%$ & $0.15 \%$ & & & & $100.00 \%$ \\
\hline
\end{tabular}




\begin{tabular}{|c|c|c|c|c|c|c|c|c|c|c|c|c|c|}
\hline & & & & Panel C: & Rural M & arkets & & & & & & & \\
\hline \multirow[t]{2}{*}{$<\$ 100 \mathrm{M}$} & 18316 & 152 & 3 & & & & & & & 2 & 0.86 & 158 & 18471 \\
\hline & $99.16 \%$ & $0.82 \%$ & $0.02 \%$ & & & & & & & & & & $100.00 \%$ \\
\hline \multirow[t]{2}{*}{$\$ 100-300 \mathrm{M}$} & 19533 & 359 & 9 & & & & & & & 2 & 1.89 & 377 & 19901 \\
\hline & $98.15 \%$ & $1.80 \%$ & $0.05 \%$ & & & & & & & & & & $100.00 \%$ \\
\hline \multirow[t]{2}{*}{$\$ 300 \mathrm{M}-\$ 1 \mathrm{~B}$} & 7669 & 264 & 19 & 1 & 1 & & & & & 4 & 3.88 & 309 & 7954 \\
\hline & $96.42 \%$ & $3.32 \%$ & $0.24 \%$ & $0.01 \%$ & $0.01 \%$ & & & & & & & & $100.00 \%$ \\
\hline \multirow[t]{2}{*}{$\$ 1-5 B$} & 210 & 14 & 4 & & & & & & & 2 & 9.65 & 22 & 228 \\
\hline & $92.11 \%$ & $6.14 \%$ & $1.75 \%$ & & & & & & & & & & $100.00 \%$ \\
\hline \multirow{2}{*}{$>\$ 5 B$} & 1 & 1 & & & & & & & & 1 & 50.00 & 1 & 2 \\
\hline & $50.00 \%$ & $50.00 \%$ & & & & & & & & & & & $100.00 \%$ \\
\hline \multirow[t]{2}{*}{ TOTAL } & 45729 & 790 & 35 & 1 & 1 & 0 & 0 & 0 & 0 & 4 & 1.86 & 866 & 46556 \\
\hline & $98.22 \%$ & $1.70 \%$ & $0.08 \%$ & $0.00 \%$ & $0.00 \%$ & $0.00 \%$ & $0.00 \%$ & $0.00 \%$ & $0.00 \%$ & & & & $100.00 \%$ \\
\hline
\end{tabular}

Notes. - Entry is defined as a new bank charter (federal or state); we exclude all entrants with gross total assets (GTA) exceeding \$1 billion by the end of the entry year. Banking markets are defined as Metropolitian Statistical Areas (MSAs) or non-MSA counties.

Sources.- U.S. Call Reports, National Information Center (NIC), and FDIC Summary of Deposits 
size classes are based on total deposits in the market, adjusted to be in constant 1994 dollars using the GDP deflator. In the smallest two market size classes (less than $\$ 300$ million in deposits), there was only about a $1-2 \%$ probability of entry and never more than two entries in the same market in the same year. These small markets had only about $14 \%$ of all entries, despite having about $73 \%$ of the total market-years. By contrast, in the largest market size class (over $\$ 5$ billion in deposits), entry occurred $51.32 \%$ of the time, with most cases of entry involving multiple entrants. On average, these large markets had 158.28 entrants per 100 markets per year, or more than 1.5 entrants per market per year. The 2,094 entries in these large markets account for more than half of all 3,875 de novo entries, although these markets account for less than $3 \%$ of the total market-years.

Panels B and C of table 1 segment the data by metropolitan (MSA) versus rural (non-MSA) markets. Of the 1,323 market years with deposits over $\$ 5$ billion, 1,321 are MSAs and only 2 are rural. By contrast, of the 38,389 market years with deposits under $\$ 300$ million, 38,372 are rural and only 17 are MSAs. In the middle size classes in which both metropolitan and rural markets are well represented, metropolitan markets appear to have substantially higher probabilities of entry and greater numbers of entrants per market.

Based on these findings, we conduct separate multivariate analyses for three subsets of the data: (1) large metropolitan markets (deposits $>\$ 5$ billion); (2) small metropolitan markets (deposits $\leq \$ 5$ billion); and (3) rural markets of all sizes. This segmentation provides a better chance of disentangling the effects of M\&As from the effects of market size and market type, which are highly correlated with both entry and M\&A activity.

In table 2, Panels A, B, and C show the frequency of entry by year and by whether or not there was M\&A activity in the local market in the previous years, that is, by whether or not at least one local bank survived a merger of bank charters or was acquired by a different toptier bank holding company (BHC) in the three prior years. As discussed, we hypothesize that recent M\&As in the local market increase the probability of entry, and the data strongly support this hypothesis. In every year of the sample, (1) the overwhelming majority of de novo entries were in markets with recent M\&A activity, (2) the frequency of entry per market was much higher in markets with M\&A activity, and (3) entries per 100 markets were many times higher in M\&A markets than in non-M\&A markets. To illustrate, in 1998, (1) M\&A markets had 188 entries versus 2 entries in non-M\&A markets, (2) M\&A markets had entry $5.77 \%$ of the time versus $0.33 \%$ of the time in nonM\&A markets, and (3) M\&A markets had 8.68 entries per 100 markets versus 0.33 entries per 100 non-M\&A markets. These results also 
TABLE 2

Commercial Bank De Novo Entry by Prior M\&A Activity and by State Banking Regulations

\begin{tabular}{|c|c|c|c|c|c|c|c|c|c|c|c|c|}
\hline \multirow[b]{2}{*}{ Year } & \multicolumn{4}{|c|}{$\begin{array}{l}\text { A: ENTRY IN MARKETS WITH } \\
\text { PRIOR M\&A ACTIVITY }\end{array}$} & \multicolumn{4}{|c|}{$\begin{array}{l}\text { B: ENTRY IN MARKETS WITHOUT } \\
\text { PRIOR M\&A ACTIVITY }\end{array}$} & \multicolumn{4}{|c|}{ C: ENTRY IN ALL MARKETS } \\
\hline & $\begin{array}{l}\text { Number } \\
\text { of Entrants }\end{array}$ & $\begin{array}{l}\text { Percent } \\
\text { with Entry }\end{array}$ & $\begin{array}{l}\text { Entrants } / 100 \\
\text { Markets }\end{array}$ & $\begin{array}{l}\text { Number } \\
\text { of Markets }\end{array}$ & $\begin{array}{l}\text { Number } \\
\text { of Entrants }\end{array}$ & $\begin{array}{l}\text { Percent } \\
\text { with Entry }\end{array}$ & $\begin{array}{l}\text { Entrants } / 100 \\
\text { Markets }\end{array}$ & $\begin{array}{c}\text { Number } \\
\text { of Markets }\end{array}$ & $\begin{array}{l}\text { Number } \\
\text { of Entrants }\end{array}$ & $\begin{array}{l}\text { Percent } \\
\text { with Entry }\end{array}$ & $\begin{array}{c}\text { Entrants/100 } \\
\text { Markets }\end{array}$ & $\begin{array}{l}\text { Number } \\
\text { of Markets }\end{array}$ \\
\hline 1980 & 143 & $9.69 \%$ & 19.51 & 733 & 70 & $3.11 \%$ & 3.46 & 2025 & 213 & $4.86 \%$ & 7.72 & 2758 \\
\hline 1981 & 149 & $8.61 \%$ & 18.06 & 825 & 61 & $2.63 \%$ & 3.15 & 1937 & 210 & $4.42 \%$ & 7.60 & 2762 \\
\hline 1982 & 231 & $9.32 \%$ & 25.33 & 912 & 90 & $4.11 \%$ & 4.87 & 1849 & 321 & $5.83 \%$ & 11.63 & 2761 \\
\hline 1983 & 295 & $9.35 \%$ & 28.72 & 1027 & 77 & $3.45 \%$ & 4.43 & 1737 & 372 & $5.64 \%$ & 13.46 & 2764 \\
\hline 1984 & 326 & $9.11 \%$ & 27.26 & 1196 & 82 & $3.95 \%$ & 5.22 & 1570 & 408 & $6.18 \%$ & 14.75 & 2766 \\
\hline 1985 & 286 & $9.12 \%$ & 21.92 & 1305 & 50 & $3.08 \%$ & 3.42 & 1462 & 336 & $5.93 \%$ & 12.14 & 2767 \\
\hline 1986 & 233 & $7.56 \%$ & 16.32 & 1428 & 26 & $1.93 \%$ & 1.93 & 1344 & 259 & $4.83 \%$ & 9.34 & 2772 \\
\hline 1987 & 203 & $7.24 \%$ & 13.36 & 1520 & 14 & $1.13 \%$ & 1.13 & 1243 & 217 & $4.49 \%$ & 7.85 & 2763 \\
\hline 1988 & 221 & $7.27 \%$ & 14.73 & 1500 & 17 & $1.35 \%$ & 1.35 & 1256 & 238 & $4.57 \%$ & 8.64 & 2756 \\
\hline 1989 & 194 & $6.83 \%$ & 12.75 & 1522 & 9 & $0.72 \%$ & 0.72 & 1250 & 203 & $4.08 \%$ & 7.32 & 2772 \\
\hline 1990 & 159 & $6.56 \%$ & 10.43 & 1524 & 11 & $0.88 \%$ & 0.88 & 1247 & 170 & $4.01 \%$ & 6.13 & 2771 \\
\hline 1991 & 104 & $4.86 \%$ & 6.32 & 1645 & 10 & $0.89 \%$ & 0.89 & 1126 & 114 & $3.25 \%$ & 4.11 & 2771 \\
\hline 1992 & 73 & $3.36 \%$ & 4.54 & 1609 & 6 & $0.52 \%$ & 0.52 & 1162 & 79 & $2.17 \%$ & 2.85 & 2771 \\
\hline 1993 & 59 & $2.94 \%$ & 3.62 & 1630 & 4 & $0.35 \%$ & 0.35 & 1134 & 63 & $1.88 \%$ & 2.28 & 2764 \\
\hline 1994 & 44 & $2.35 \%$ & 2.59 & 1702 & 4 & $0.37 \%$ & 0.37 & 1075 & 48 & $1.58 \%$ & 1.73 & 2777 \\
\hline 1995 & 97 & $3.78 \%$ & 5.02 & 1933 & 7 & $0.83 \%$ & 0.83 & 844 & 104 & $2.88 \%$ & 3.75 & 2777 \\
\hline 1996 & 144 & $5.21 \%$ & 7.08 & 2034 & 4 & $0.54 \%$ & 0.54 & 743 & 148 & $3.96 \%$ & 5.33 & 2777 \\
\hline 1997 & 178 & $6.29 \%$ & 8.48 & 2099 & 4 & $0.59 \%$ & 0.59 & 677 & 182 & $4.90 \%$ & 6.56 & 2776 \\
\hline 1998 & 188 & $5.77 \%$ & 8.68 & 2166 & 2 & $0.33 \%$ & 0.33 & 607 & 190 & $4.58 \%$ & 6.85 & 2773 \\
\hline
\end{tabular}


TABLE 2

\begin{tabular}{|c|c|c|c|c|c|c|c|c|c|c|c|c|}
\hline \multirow[b]{2}{*}{ Year } & \multicolumn{4}{|c|}{ D: UNIT BANKING STATES } & \multicolumn{4}{|c|}{ E: LIMITED BRANCHING STATES } & \multicolumn{4}{|c|}{ F: STATEWIDE BRANCHING STATES } \\
\hline & $\begin{array}{l}\text { Number } \\
\text { of Entrants }\end{array}$ & $\begin{array}{c}\text { Percent } \\
\text { with Entry }\end{array}$ & $\begin{array}{c}\text { Entrants/100 } \\
\text { Markets }\end{array}$ & $\begin{array}{c}\text { Number } \\
\text { of Markets }\end{array}$ & $\begin{array}{l}\text { Number } \\
\text { of Entrants }\end{array}$ & $\begin{array}{c}\text { Percent } \\
\text { with Entry }\end{array}$ & $\begin{array}{c}\text { Entrants/100 } \\
\text { Markets }\end{array}$ & $\begin{array}{c}\text { Number } \\
\text { of Markets }\end{array}$ & $\begin{array}{c}\text { Number } \\
\text { of Entrants }\end{array}$ & $\begin{array}{c}\text { Percent } \\
\text { with Entry }\end{array}$ & $\begin{array}{c}\text { Entrants/100 } \\
\text { Markets }\end{array}$ & $\begin{array}{c}\text { Number } \\
\text { of Markets }\end{array}$ \\
\hline 1980 & 95 & $5.85 \%$ & 9.92 & 958 & 62 & $3.93 \%$ & 4.60 & 1347 & 56 & $6.65 \%$ & 14.89 & 376 \\
\hline 1981 & 99 & $5.08 \%$ & 11.17 & 886 & 58 & $3.66 \%$ & 4.08 & 1422 & 53 & $6.63 \%$ & 14.06 & 377 \\
\hline 1982 & 154 & $7.68 \%$ & 17.40 & 885 & 97 & $4.73 \%$ & 6.95 & 1396 & 70 & $6.72 \%$ & 17.41 & 402 \\
\hline 1983 & 201 & $9.09 \%$ & 26.87 & 748 & 90 & $3.91 \%$ & 5.87 & 1534 & 81 & $6.93 \%$ & 20.05 & 404 \\
\hline 1984 & 190 & $9.97 \%$ & 32.09 & 592 & 141 & $4.52 \%$ & 8.38 & 1682 & 77 & $8.70 \%$ & 18.60 & 414 \\
\hline 1985 & 142 & $8.26 \%$ & 23.95 & 593 & 140 & $5.02 \%$ & 8.37 & 1672 & 54 & $7.31 \%$ & 12.74 & 424 \\
\hline 1986 & 95 & $7.25 \%$ & 16.02 & 593 & 118 & $3.86 \%$ & 7.35 & 1606 & 46 & $5.89 \%$ & 9.35 & 492 \\
\hline 1987 & 40 & $4.06 \%$ & 6.77 & 591 & 126 & $3.88 \%$ & 7.88 & 1600 & 51 & $7.66 \%$ & 10.28 & 496 \\
\hline 1988 & 18 & $3.74 \%$ & 8.41 & 214 & 163 & $4.66 \%$ & 8.94 & 1824 & 57 & $5.16 \%$ & 8.91 & 640 \\
\hline 1989 & 17 & $4.19 \%$ & 7.91 & 215 & 63 & $2.48 \%$ & 4.46 & 1413 & 123 & $6.53 \%$ & 11.64 & 1057 \\
\hline 1990 & 19 & $4.19 \%$ & 8.84 & 215 & 59 & $2.96 \%$ & 4.60 & 1283 & 92 & $5.40 \%$ & 7.76 & 1186 \\
\hline 1991 & 2 & $3.51 \%$ & 3.51 & 57 & 34 & $2.45 \%$ & 3.21 & 1060 & 78 & $3.96 \%$ & 4.98 & 1567 \\
\hline 1992 & & & & & 25 & $1.97 \%$ & 2.47 & 1014 & 54 & $2.40 \%$ & 3.23 & 1670 \\
\hline 1993 & & & & & 21 & $1.58 \%$ & 2.07 & 1014 & 42 & $2.16 \%$ & 2.52 & 1666 \\
\hline 1994 & & & & & 13 & $1.29 \%$ & 1.40 & 927 & 35 & $1.82 \%$ & 1.99 & 1758 \\
\hline 1995 & & & & & 23 & $2.16 \%$ & 2.48 & 927 & 81 & $3.41 \%$ & 4.61 & 1757 \\
\hline 1996 & & & & & 47 & $3.88 \%$ & 5.07 & 927 & 101 & $4.21 \%$ & 5.75 & 1757 \\
\hline 1997 & & & & & 52 & $4.32 \%$ & 5.62 & 926 & 130 & $5.46 \%$ & 7.40 & 1757 \\
\hline 1998 & & & & & 34 & $2.88 \%$ & 3.92 & & 156 & $5.63 \%$ & 8.61 & 1812 \\
\hline
\end{tabular}

NoтE.- Entry is defined as a new bank charter (federal or state); we exclude all entrants with gross total assets (GTA) exceeding \$1 billion by the end of the entry year. Banking markets are defined as MSAs or non-MSA counties. A market is considered to have prior M\&A activity if in any of the previous three years, any bank in the market was involved in a merger (two or more bank charters were consolidated) or an acquisition (charter retained but change of bank holding company ownership).

Unit banking regulations generally allow only one full service office per bank.

Banks in limited branching states can have multiple branches, but these are restricted in some way (e.g., branches in only one county).

Banks in statewide branching states face no limitations on within-state branching.

SourCES.- U.S. Call Reports; National Information Center (NIC); FDIC Summary of Deposits; Berger, Kashyap, and Scalise (1995); and Conference of State Bank Supervisors. 
depend on other factors that we try to control for in our multivariate analysis. Nonetheless, the raw data are quite one-sided and fairly persuasive on their own.

Two other findings are apparent from these data. First, the proportion of markets with recent M\&A activity increased steadily over time, from less than $30 \%$ at the beginning of the period to over $75 \%$ at the end. Second, there was substantially more entry in the U.S. banking industry in the 1980s than in the 1990s, with over 200 entries in every year in the 1980s. One reason for the high frequency of entry in the 1980s may be a liberalization of charter policy at that time. Beginning in 1980, the Office of the Comptroller of the Currency began to pay less attention to a community's "capacity" to support an additional bank in granting national bank charters and allow market competition to determine entry and exit (White 1992).

In contrast with the 1980 s, there were fewer than 200 entries in every year of the 1990s (through 1998), including a low of just 48 entries in 1994. However, there was a substantial upswing over the period 1995-1998, with a local maximum of 190 entrants in 1998. The percent of markets with entry and the number of entries per 100 market years were generally lower in the 1990s as well. ${ }^{7}$

Panels D, E, and F of table 2 show entry statistics classified by state banking regulations each year. ${ }^{8}$ Unit banking regulations generally allow only one full service office per bank. Banks in limited branching states can have multiple branches but are restricted in some way (e.g., branches in only one county). Over time, state geographic regulations were substantially liberalized, and by the end of 1991, all unit banking regulations had been eliminated.

As discussed, we hypothesize that the state restrictions on competition from existing firms outside the local market would create market power and thereby increase de novo entry. In some cases, de novo entry might be newly chartered banks opened by bank holding companies as alternatives to establishing new branches where branching is prohibited. For example, several BHCs owned a number of individual banks in Texas in the 1980s, which was a unit banking state until 1987.

7. The frequency of entry over time does not correspond as well as might be expected with aggregate banking industry profitability. Profitability was generally falling during the mid-1980s, while entries were rising to their sample peaks. As well, the run of high profitability began in the early 1990s, with record profits being reached in 1993 and 1994, the years with the fewest entries. However, entries increased in the 1995-1998 time interval, congruent with the strong aggregate profitability and other favorable conditions for the banking industry of these years.

8. To be consistent with our empirical analysis, the state rules shown in table 2 are those in effect as of December 31 of the prior year. This reduces endogeneity problems and assures that the explanatory variables are known to those making the entry decisions. 
The data are only somewhat consistent with these predictions. During the 1980s, unit banking markets generally had higher percentages of entry and more entries per 100 markets than markets in limited branching states but were not much different on average from markets in statewide branching states. Presumably, markets in statewide branching states had statistics comparable to unit banking states because statewide branching states tend to be those with relatively large markets (e.g., California). This is controlled for in our multivariate analysis.

A final set of findings not shown in the tables concerns de novo entry by thrift institutions (savings and loans and savings banks). For our main analysis, we include only commercial bank entry, since thrifts typically do not compete effectively in the business loan market. As discussed earlier, a policy question we address is the extent to which any external effect of M\&As on the small business lending of other local lenders operates through de novo entry. Thrift institutions typically devote an even smaller percentage of their assets to small business loans than do the very largest commercial banks, so thrift entry generally is not a significant part of the external effect of M\&As at issue here (Kwan 1998). Nonetheless, we include thrift entry as a robustness check because many thrift products are substitutes for bank products.

There were 743 thrift entries over our full time period of 1980 1998 , about $20 \%$ as many as commercial bank entries. Many of the thrift entries occurred in the same markets in the same years as commercial bank entries, so the percent of market years with entry by commercial banks or thrifts was $4.65 \%$, not much above the $4.21 \%$ that commercial banks alone entered. Importantly, the thrift entries do not alter the finding that entries occur much more often if there was bank M\&A activity in the local market in the prior 3 years. Over the 1995-1998 subperiod, M\&A markets had 65 thrift entries versus 1 thrift entry in non-M\&A markets. If anything, the thrift entry data are even more one-sided than the commercial bank entry data shown in table 2, strongly suggesting that M\&A activity is associated with increased likelihood of entry.

\section{Hypotheses and Methodology}

In this section, we outline our main hypotheses to be tested and our empirical methodology. The hypotheses concern factors that may affect the likelihood of de novo entry in a banking market, and we develop empirical models of entry to test these hypotheses. The variables used in the main entry regressions are described in detail in table 3, along with the sample means and standard deviations of these variables for the large metropolitan, small metropolitan, and rural 


\begin{tabular}{lcc}
\hline & Large MSAs & Rural Markets \\
\hline Symbol & MSAs & Mean \\
(Standard Dev.) & Mean
\end{tabular}

\section{Dependent Variable}

ENTRY

Dummy variable, equals 1 for any positive bank entry, in a given banking market, in a given year. Entry is defined as a new bank charter (federal or state); we exclude all entrants with gross total assets (GTA) exceeding \$1 billion by the end of the entry year and all commercial banks with bank types coded as subject to special analysis, such as bankers' banks, credit card banks, depository trust companies, and bridge entities. Banking markets are defined as MSAs or non-MSA counties. Source: National Information Center.

\section{Independent Variables}

Market Mergers and Acquisitions (M\&As)

MKT-MERGE Share of local market deposits in banks involved in mergers in which two or more bank charters are consolidated, averaged over the previous 3 years. Source: National Information Center.

MKT-ACQUIS

Share of local market deposits in banks involved in acquisitions in which the banks retain their separate charters but their top-tier bank-holdingcompany ownership changes, averaged over the previous 3 years. Source: National Information

Center.

$\begin{array}{ccc}0.181 & 0.136 & 0.068 \\ (0.152) & (0.137) & (0.126) \\ & & \\ 0.035 & 0.041 & 0.026 \\ (0.049) & (0.062) & (0.064)\end{array}$

$\begin{array}{ccc}0.489 & 0.142 & 0.018 \\ (0.500) & (0.349) & (0.134)\end{array}$


TABLE 3

(Continued)

\begin{tabular}{|c|c|c|c|c|}
\hline & & Large MSAs & Small MSAs & Rural Markets \\
\hline Symbol & Definition & $\begin{array}{c}\text { Mean } \\
\text { (Standard Dev.) }\end{array}$ & $\begin{array}{c}\text { Mean } \\
\text { (Standard Dev.) }\end{array}$ & $\begin{array}{c}\text { Mean } \\
\text { (Standard Dev.) }\end{array}$ \\
\hline
\end{tabular}

\section{Other Competitive Conditions}

MKT-HERF

MKT-SHAREL

MKT-SHAREM

MKT-SHAREC

UNITB
Local market Herfindahl index for the previous year, based on deposits. The Herfindahl index is the sum of the squared market shares of all banks in the market. Source: FDIC Summary of Deposits.

0.154

$(0.071)$

0.201

$(0.082)$

0.422

Share of market deposits held by large banks

(GTA > \$1B) for the previous year. GTA equals total assets plus loan and lease loss reserves and

allocated transfer risk reserve (a reserve for

certain foreign loans). Sources: U.S. Call Reports; FDIC Summary of Deposits.

Share of market deposits held by medium-size banks (GTA \$100M-\$1B) for the previous year. Sources: U.S. Call Reports; FDIC Summary of Deposits.

Share of market deposits held by complex banks (owned by out-of-state or multilayered bank holding company) for the previous year. Source: U.S. Call Reports; FDIC Summary of Deposits.

Dummy variable, equals 1 for a unit banking state as of the previous year. Unit banking states generally allow only one full service office per bank. Sources: Berger, Kashyap, and Scalise (1995); Conference of State Bank Supervisors.
0.744

$(0.174)$

0.189

$(0.123)$

0.274

$(0.252)$

(0.272)

0.381

(0.331)

0.472

(0.278)

0.240

0.062

(0.242)
0.164

(0.300)

0.234

(0.247)

0.134

(0.341) 
LIMITB

NEWLIB

INTST

Market Demand Conditions

MKT-GROW

STINCOME

MKT-PFRAT

MKT-LNDEP
Dummy variable, equals 1 for a limited branching state as of the previous year. Limited branching states

generally permit a bank to have multiple branches,

but these are restricted in some way (e.g., branches in only one county). (Statewide branching dummy is excluded from the regressions as the base case).

Sources: Berger et al. (1995); Conference of

State Bank Supervisors.

Dummy variable, equals 1 if the state moved to a more liberal branching rule during the previous year.

Sources: Berger et al. (1995); Conference of State

Bank Supervisors.

Dummy variable, equals 1 for indicating that interstate bank holding company expansion was allowed as of the previous year. Sources: Berger et al. (1995);

Conference of State Bank Supervisors.

Growth rate of market deposits for the previous year. Source: FDIC Summary of Deposits.

Real state income growth for the previous year. Source: U.S. Department of Commerce.

Ratio of purchased funds/GTA (market averages) for the previous year. Purchased funds are time deposits over $\$ 100,000$, foreign deposits, federal funds purchased, demand notes issued to the U.S. Treasury, trading

liabilities, other borrowed money, mortgage

indebtedness and obligations under capitalized leases, and subordinated notes and debentures. Source: U.S.

Call Reports.

Market size (log of market deposits) for the previous year. Source: FDIC Summary of Deposits.
0.362

0.431

$(0.495)$

0.489

$(0.481)$

$(0.500)$

0.042

$(0.200)$

0.046

$(0.211)$

0.045

$(0.207)$

0.687

0.599

$(0.490)$

0.578

$(0.464)$

0.035

(0.195)

0.033

(0.024)

0.302

(0.111)

0.022

$(0.187)$

0.031

(0.027)

0.214

(0.088)

0.035

(0.973)

0.030

$(0.028)$

0.147

(0.081) 


\begin{tabular}{|c|c|c|c|c|}
\hline & & Large MSAs & Small MSAs & Rural Markets \\
\hline Symbol & Definition & $\begin{array}{c}\text { Mean } \\
\text { (Standard Dev.) }\end{array}$ & $\begin{array}{c}\text { Mean } \\
\text { (Standard Dev.) }\end{array}$ & $\begin{array}{c}\text { Mean } \\
\text { (Standard Dev.) }\end{array}$ \\
\hline MKT-MDEP1 & $\begin{array}{l}\text { Dummy variable, equals } 1 \text { if the metropolitan market } \\
<\$ 1 \mathrm{~B} \text { in deposits for the previous year. (This } \\
\text { variable is excluded as the base case in the } 1995- \\
1998 \text { subperiod regressions.) Source: FDIC } \\
\text { Summary of Deposits. }\end{array}$ & - & $\begin{array}{c}0.329 \\
(0.470)\end{array}$ & - \\
\hline MKT-MDEP2 & $\begin{array}{l}\text { Dummy variable, equals } 1 \text { for metropolitan markets } \\
\$ 1 \mathrm{~B}-\$ 5 \mathrm{~B} \text { in deposits for the previous year. (This } \\
\text { variable is excluded as the base case in the } 1980- \\
1998 \text { full sample period regressions.) Source: FDIC } \\
\text { Summary of Deposits. }\end{array}$ & - & $\begin{array}{c}0.671 \\
(0.470)\end{array}$ & - \\
\hline MKT-RDEP2 & $\begin{array}{l}\text { Dummy variable, equals } 1 \text { for rural market } \$ 100 \mathrm{M}- \\
\$ 300 \mathrm{M} \text { in deposits for the previous year. (Dummy } \\
\text { for rural markets less than } \$ 100 \mathrm{M} \text { is excluded as } \\
\text { the base case in rural market regressions.) Source: } \\
\text { FDIC Summary of Deposits. }\end{array}$ & - & - & $\begin{array}{c}0.445 \\
(0.497)\end{array}$ \\
\hline MKT-RDEP3 & $\begin{array}{l}\text { Dummy variable, equals } 1 \text { for rural markets greater } \\
\text { than } \$ 300 \mathrm{M} \text { in deposits for the previous year. } \\
\text { Source: FDIC Summary of Deposits. }\end{array}$ & - & - & $\begin{array}{c}0.183 \\
(0.387)\end{array}$ \\
\hline \multicolumn{5}{|l|}{ Market Prices } \\
\hline MKT-P1 & $\begin{array}{l}\text { Market average price of consumer loans (installment, } \\
\text { credit cards, and related plans to individuals, from } \\
\text { the bank's domestic offices) for the previous year. } \\
\text { Price is interest income on consumer loans less } \\
\text { provision for loan and lease losses and allocated } \\
\text { transfer risk allocated to consumer loans, divided by } \\
\text { stock of consumer loans. Source: U.S. Call Reports. }\end{array}$ & $\begin{array}{c}0.092 \\
(0.036)\end{array}$ & $\begin{array}{c}0.083 \\
(0.048)\end{array}$ & $\begin{array}{c}0.070 \\
(0.061)\end{array}$ \\
\hline
\end{tabular}


etc.) for the previous year. Price is interest

income on business loans less provision for loan and lease losses and allocated transfer risk allocated to business loans, divided by stock of business loans. Source: U.S. Call Reports.

MKT-P3

Market average price of real estate loans for the previous year. Price is interest income on real estate loans less provision for loan and lease losses and allocated transfer risk allocated to real estate loans, divided by stock of real estate loans.

Source: U.S. Call Reports.

MKT-P4

MKT-W1

MKT-W2

MKT-W3
Market average price of securities (all nonloan financial assets) for the previous year. Price is interest income on securities, divided by stock of securities. Source: U.S. Call Reports.

Market average price of purchased funds for the previous year. Price is expense of purchased funds, divided by stock of purchased funds.

Source: U.S. Call Reports.

Market average price of core deposits (domestic transactions accounts, time deposits under $\$ 100,000$, and savings deposits) for the previous year. Price is expense of core deposits, divided by stock of core deposits. Source: U.S. Call

Reports.

Market average price of labor (salary plus benefits, in 1000s of constant 1994 dollars, per employee) for the previous year. Source: U.S. Call Reports. 


\begin{tabular}{|c|c|c|c|c|}
\hline & & Large MSAs & Small MSAs & Rural Markets \\
\hline Symbol & Definition & $\begin{array}{c}\text { Mean } \\
\text { (Standard Dev.) }\end{array}$ & $\begin{array}{c}\text { Mean } \\
\text { (Standard Dev.) }\end{array}$ & $\begin{array}{c}\text { Mean } \\
\text { (Standard Dev.) }\end{array}$ \\
\hline \multicolumn{5}{|c|}{ Condition of Market Banks } \\
\hline MKT-ROE & $\begin{array}{l}\text { Average return on equity (net income, divided } \\
\text { by total equity capital) in market for the } \\
\text { previous year. Source: U.S. Call Reports. }\end{array}$ & $\begin{array}{c}0.106 \\
(0.105)\end{array}$ & $\begin{array}{c}0.115 \\
(0.092)\end{array}$ & $\begin{array}{c}0.112 \\
(0.113)\end{array}$ \\
\hline MKT-NPL & $\begin{array}{l}\text { Market average nonperforming loan ratio for } \\
\text { the previous year. Nonperforming loan ratio } \\
\text { is loans past due at least } 30 \text { days or on a } \\
\text { nonaccrual basis, divided by total loans. } \\
\text { Source: U.S. Call Reports. }\end{array}$ & $\begin{array}{c}0.030 \\
(0.025)\end{array}$ & $\begin{array}{c}0.025 \\
(0.023)\end{array}$ & $\begin{array}{c}0.029 \\
(0.029)\end{array}$ \\
\hline MKT-EQRAT & $\begin{array}{l}\text { Market average equity (net income)/GTA ratio } \\
\text { for the previous year. Source: U.S. Call } \\
\text { Reports. }\end{array}$ & $\begin{array}{c}0.067 \\
(0.012)\end{array}$ & $\begin{array}{c}0.074 \\
(0.012)\end{array}$ & $\begin{array}{c}0.087 \\
(0.020)\end{array}$ \\
\hline MKT-EFFIC & $\begin{array}{l}\text { Market average cost efficiency measure (the } \\
\text { negative of the market average residual } \\
\text { from estimated cost function) for the } \\
\text { previous year. Sources: U.S. Call reports and } \\
\text { authors' calculations. }\end{array}$ & $\begin{array}{c}0.004 \\
(0.070)\end{array}$ & $\begin{array}{l}-0.005 \\
(0.075)\end{array}$ & $\begin{array}{r}-0.012 \\
(0.090)\end{array}$ \\
\hline \multicolumn{5}{|c|}{ Temporal Conditions } \\
\hline D1981-D1998 & $\begin{array}{l}\text { Dummy variables for years } 1981-1998 \text { (1980 is } \\
\text { the base case). }\end{array}$ & & & \\
\hline
\end{tabular}

Notes.-All financial values are measured in real 1994 dollars using the GDP deflator.

All variables with the MKT prefix refer to local-market-based measures. Where these variables are constructed from individual bank data (e.g., MKT-P1, MKT-NPL), the resulting market values are weighted averages of the variable values for the banks that have deposits in a specific market, where the weights are the banks' deposit shares in that market.

For additional details, see the data appendix at http://pages.stern.nyu.edu/ ${ }^{\sim}$ lwhite/bbgw.stat.app.htm. 
markets. In the interest of brevity, variables used only in the robustness checks are not shown in the tables.

\section{A. Hypotheses about Entry}

The major hypotheses about the causes of entry concern the expected future profitability of a prospective entrant. We focus first on the expected future profit opportunities afforded by M\&A activity in the local market. As indicated already, M\&As may affect expected profitability from entry by (1) changing the exercise of market power in setting prices in the local market, (2) changing the efficiency of the M\&A participants or other local competitors, and (3) altering the supply of services to small relationship-based customers in the local market.

Based on the evidence summarized previously, the third effect of bank M\&As on entry (the external effect from a possible reduction in the supply of services to small customers by banks engaging in M\&As) is likely to be the strongest. Potential M\&As that would result in large increases in market power likely do not occur often because of antitrust authorities or fear of entry or responses of other competitors. The only pronounced efficiency gains from bank M\&As appear to be gains from increases in diversification, which are expected to be strong only for market-extension type M\&As. In contrast, the effect of M\&As involving large banks in reducing small business lending is well established, and this the type of lending is the niche of de novo banks for a number of years after entry.

There are a number of other influences on potential entrants' expectations of future profitability and hence on entry. As indicated, the literature often focuses on the recent profitability of incumbent firms, recent market growth, and the level of market concentration as proxies for expected future profits. Generally, recent profits, growth, and concentration are expected to have positive effects on the probability of entry, all else equal, although concentration is sometimes thought to have a negative effect on the probability of entry because high concentration may be an indicator of high barriers to entry that are difficult to measure. We include these variables in our empirical model. We hypothesize that the effects of profitability and growth are positive and the effects of concentration depend on whether it is more of a proxy for high profit opportunities or high entry barriers.

We also include two variables that are similar in spirit to market growth. The market's ratio of purchased funds to total assets is included as an indicator of lending opportunities that exceed locally generated deposits. Similarly, state income growth is an indicator of future profitable opportunities for new banks and is hypothesized to have a positive effect on the likelihood of entry. 
The entry literature often includes measures of barriers to entry. As discussed, the state banking regulations, such as unit banking rules, act as barriers to entry by incumbent firms from other markets but are not barriers to de novo entry. As shown in table 3, we include a number of variables measuring these restrictions, including indicators of unit banking restrictions, limited branching restrictions, and recent changes in these restrictions. We hypothesize that legal restrictions on branching by existing banks increase the probability of de novo entry by creating local market power. We also include a variable for whether BHCs from out of state may enter the market. The effect of this variable is ambiguous, since state laws differ and some of them affect both barriers to acquisitions by existing institutions and barriers to de novo entry.

In addition, we include specific average market prices for major outputs (consumer loans, non-real-estate business loans, real estate loans, and securities) and inputs (purchased funds, core deposits, and labor). We hypothesize that the probability of entry is increasing in the output prices and decreasing in the input prices, all else equal, as high output prices and low input prices are associated with profit opportunities. However, the prices that are interest rates (all but the labor price) may reflect differences in risk across banking markets. High average market rates charged on loans could reflect high default premiums for lending to local customers, and high rates paid on liabilities could reflect high relatively high bankruptcy probabilities for local banks. If these risks deter entry, this could reverse the hypothesized signs on the outputs (e.g., high loan rates would reduce the probability of entry) but would reinforce the predicted signs on the funding inputs (e.g., high rates would reduce the probability of entry because of both low market power and high bankruptcy risk).

We also include a number of other factors shown in table 3. We hypothesize that the presence of larger or more organizationally complex banks increase the probability of entry, as large or complex banks may be competitively disadvantaged in serving the small business (relationship) customer niche in which de novo banks tend to specialize. Therefore, we include variables for market shares of large banks, medium-sized banks, and complex banks (small and noncomplex banks are the base groups). We also include measures of the efficiency and financial condition of market banks, given that moreefficient or financially sound incumbents should make stronger competitors, which is likely to deter entry. However, it is alternatively possible that better-performing incumbents in a market is a proxy for favorable market conditions, which may encourage entry. Further, as discussed, we control for the size of the banking market and whether it is metropolitan or rural. Finally, to control for purely temporal effects, 
we include annual dummy variables for the years after the initial year of our sample. As shown in table 3, we group our explanatory variables into six broad categories: Market M\&As, Other Competitive Conditions, Market Demand Conditions, Market Prices, Condition of Market Banks, and Temporal Conditions.

\section{B. Methodology}

We model the probability of entry based on M\&As in the market and other market variables hypothesized to affect the prospects for profitable entry. We estimate the model a number of different ways for several subsets of the data based on the sample period, market size, and market type, but the main model is a simple logit equation of the probability of entry in market $\mathrm{m}$ in year $\mathrm{t}$, which takes the form:

$$
\begin{aligned}
& \ln \left(\mathrm { P } \left(\text { ENTRY }_{m, t} /\left(1-\mathrm{P}\left(\mathrm{ENTRY}_{\mathrm{m}, \mathrm{t}}\right)\right)=f\left(\text { MARKET M\&A }_{m, t-1, t-2, t-3},\right.\right.\right. \\
& \text { OTHER COMPETITIVE CONDITIONS } \\
& m, t-1 \\
& \text { MARKET DEMAND CONDITIONS }_{m, t-1}, \\
& \text { MARKET PRICES } \\
& m, t-1 \text { CONDITION } \\
& \text { OF MARKET BANKS } \\
& \text { TEMPORAL CONDITIONS } \\
&
\end{aligned}
$$

The data are annual, and entry is measured as having occurred or not occurred during year $t$ in market $m$. All the right-hand-side variables are measured as of the end of year $t-1$ or earlier to reduce endogenous feedback effects. For expositional clarity, most of these explanatory variables shown in table 3 have the prefix MKT, indicating that they are calculated for the market. In most cases, these are averages over the banks that have deposits in the market weighted by each bank's share of these deposits. Other right-hand-side variables, such as the banking regulations, are for the state in which the market is located.

Because prior research suggests that different types of M\&As may have different effects, we distinguish among the effects of different types of consolidation. As shown in table 3, the MARKET M\&A variables included in our main model measure the proportion of market deposits involved in recent bank mergers (MKT-MERGE), in which two or more bank charters are consolidated, and the proportion involved in BHC acquisitions (MKT-ACQUIS), in which the banks retain their separate charters but their top-tier BHC ownership is changed. For any merger of bank charters, the variable MKT-MERGE rises in every market in which any of the merger partners had deposits. Similarly, for any acquisition by a top-tier BHC of a group of banks or another BHC that owns a group of banks, MKT-ACQUIS rises in every market in which any of the directly acquired banks or banks in 
BHCs that were acquired had deposits. In our robustness checks, we also distinguish between in-market and market-extension mergers, mergers in which the pro forma consolidated bank is small versus large, and mergers among BHC affiliates versus mergers of previously unaffiliated banks.

We include 3 past years of M\&As because prior analyses of bank M\&As and reports by bank consultants suggest that at least 3 years are needed as a gestation period to complete any restructuring or refocusing of a bank after an M\&A (e.g., Cornett and Tehranian 1992; Toevs 1992; Berger, Saunders, Scalise, and Udell 1998). The external effect is likely to take at least as long as the effects on the institutions involved in the M\&As, implying that a minimum of 3 years is necessary for the analysis. As well, the financial press reports that it often takes 1-3 years after an M\&A for the departing loan officers to start a rival de novo bank (e.g., Epstein 1996). The main regressions we report specify the average over years $t-1, t-2$, and $t-3$ of the proportions of local market deposits in the offices of banks that were involved in mergers or acquisitions. As shown later, the results are robust with respect to an alternative specification in which the three individual annual lags are included. ${ }^{9}$

\section{Empirical Results}

Tables $4 \mathrm{a}$ and $4 \mathrm{~b}$ show the results of the simple logit model of the probability of entry in equation (1). Table 4a applies the model to large metropolitan markets, small metropolitan markets, and rural markets for the full 1980-1998 period, and table 4b repeats the exercise for the 1995-1998 subperiod, in which entry increased considerably. The full time period has the advantage of more observations and coverage of a broad range of macroeconomic, interest rate, and bank regulatory conditions; and it may be more appropriate for testing the economic hypotheses over the long term. The 1995-1998 subperiod may be closer to the conditions for entry currently and in the near future. This subperiod also covers the years after passage of the Riegle-Neal Act, which may have affected both M\&A and entry decisions.

The regressions exclude a small percentage of observations because of missing or unreliable values of some of the variables. We also eliminate a few large or unusual types of de novo entries. We eliminate all entrants with GTAs exceeding \$1 billion by the end of the entry year, which may not fit our profile of small operators that enter to provide services to small business customers. We also exclude commercial

9. In the interest of brevity, we will not discuss further the other exogenous variables in the equation here. The rationales for including these variables were given in the "Hypotheses about Entry" subsection and the individual descriptions and summary statistics on these variables are given in table 3. 


\begin{tabular}{|c|c|c|c|c|c|c|}
\hline \multirow[b]{2}{*}{ Variable } & \multicolumn{2}{|c|}{$\begin{array}{l}\text { Large Metropolitan } \\
\text { Markets }\end{array}$} & \multicolumn{2}{|c|}{$\begin{array}{l}\text { Small Metropolitan } \\
\text { Markets }\end{array}$} & \multicolumn{2}{|c|}{$\begin{array}{l}\text { Rural } \\
\text { Markets }\end{array}$} \\
\hline & Parameter Estimate & Standard Error & Parameter Estimate & Standard Error & Parameter Estimate & Standard Error \\
\hline INTERCEPT & $-11.6864^{* * *}$ & 2.5992 & $-11.9593^{* * *}$ & 1.9855 & $-16.493^{* * *}$ & 1.3690 \\
\hline MKT-MERGE & $0.9936_{* * *}^{*}$ & 0.5166 & $1.2216_{* * * *}^{* * *}$ & 0.4056 & $0.9861_{* * * *}^{* * *}$ & 0.3487 \\
\hline MKT-ACQUIS & $4.1309^{* * *}$ & 1.5871 & $1.8620_{* *}^{* *}$ & 0.8087 & $1.593^{* * *}$ & 0.5308 \\
\hline MKT-HERF & -0.7165 & 1.3516 & $-1.8134^{* *}$ & 0.8007 & $1.4294^{* * * *}$ & 0.2959 \\
\hline MKT-SHAREL & $-6.3112^{* * * *}$ & 1.5173 & -0.8770 & 0.5380 & $-0.7783^{* * *}$ & 0.2379 \\
\hline MKT-SHAREM & $-6.3738_{* * *}^{* *}$ & 1.9047 & -0.7750 & 0.5057 & -0.1858 & 0.1579 \\
\hline MKT-SHAREC & $0.7054^{*}$ & 0.3705 & 0.3023 & 0.2227 & $0.7558^{* * * *}$ & 0.1574 \\
\hline UNITB & $1.1394_{* *}^{* *}$ & 0.5354 & $1.1709^{* * *}$ & 0.2085 & $1.2413_{* * * *}^{* * *}$ & 0.1467 \\
\hline LIMITB & $-0.3698^{* *}$ & 0.1844 & 0.0412 & 0.1317 & $0.3832^{* * *}$ & 0.1089 \\
\hline NEWLIB & $0.7740^{* *}$ & 0.3508 & 0.0062 & 0.2529 & 0.102 & 0.2141 \\
\hline INTST & 0.5028 & 0.3245 & -0.2000 & 0.2035 & -0.0828 & 0.1558 \\
\hline MKT-GROW & -0.0256 & 0.4502 & -0.2609 & 0.2560 & -0.3195 & 0.2047 \\
\hline STINCOME & $23.2739^{* * * *}$ & 4.8221 & $15.8351^{* * *}$ & 2.4101 & $6.5156^{* * *}$ & 1.5703 \\
\hline MKT-PFRAT & $2.6941^{* * * *}$ & 1.0204 & $2.3874^{* * * *}$ & 0.7085 & $2.5018^{* * * *}$ & 0.5597 \\
\hline MKT-LNDEP & $0.9735^{* * *}$ & 0.1329 & $0.8442^{* * *}$ & 0.1238 & $1.0841^{* * *}$ & 0.1110 \\
\hline MKT-MDEP1 & & & 0.0596 & 0.1623 & & \\
\hline MKT-RDEP2 & & & & & -0.1025 & 0.1513 \\
\hline MKT-RDEP3 & & & & & -0.2893 & 0.2320 \\
\hline MKT-P1 & 1.8835 & 4.0872 & $6.5973^{* * *}$ & 2.3601 & 2.1439 & 1.3221 \\
\hline MKT-P2 & $3.8212_{* * *}^{*}$ & 2.3035 & $2.8814^{* *}$ & 1.1623 & 0.2458 & 0.7202 \\
\hline MKT-P3 & $-14.6421^{* * *}$ & 5.1292 & $-9.4949^{* * *}$ & 2.8328 & $-2.997^{* *}$ & 1.5595 \\
\hline MKT-P4 & 11.0121 & 10.9953 & $-18.1692^{* * *}$ & 6.4697 & 0.9828 & 4.3841 \\
\hline MKT-W1 & -6.3396 & 11.044 & -1.2996 & 5.4633 & -3.2236 & 2.3606 \\
\hline MKT-W2 & -14.2945 & 9.7704 & $-17.8249^{* *}$ & 7.2445 & $-22.4935^{* * *}$ & 4.9073 \\
\hline MKT-W3 & -0.0291 & 0.0184 & $-0.0370 * *$ & 0.0147 & 0.0025 & 0.0091 \\
\hline MKT-ROE & 0.2857 & 1.0661 & $1.3389^{* *}$ & 0.6135 & $-0.6098^{* * *}$ & 0.1815 \\
\hline MKT-NPL & -5.8419 & 6.8244 & -2.3018 & 4.4054 & 0.9191 & 2.0252 \\
\hline MKT-EQRAT & 7.2557 & 10.202 & $-12.1808^{* *}$ & 5.6159 & $-10.0673^{* * *}$ & 2.8819 \\
\hline
\end{tabular}




\begin{tabular}{|c|c|c|c|c|c|c|}
\hline \multirow[b]{2}{*}{ Variable } & \multicolumn{2}{|c|}{$\begin{array}{l}\text { Large Metropolitan } \\
\text { Markets }\end{array}$} & \multicolumn{2}{|c|}{$\begin{array}{l}\text { Small Metropolitan } \\
\text { Markets }\end{array}$} & \multicolumn{2}{|c|}{$\begin{array}{l}\text { Rural } \\
\text { Markets }\end{array}$} \\
\hline & Parameter Estimate & Standard Error & Parameter Estimate & Standard Error & Parameter Estimate & Standard Error \\
\hline MKT-EFFIC & $-2.3880^{* *}$ & 1.1779 & $-1.6744_{* *}^{* *}$ & 0.6543 & -0.3633 & 0.4519 \\
\hline D1981 & 0.2111 & 0.498 & $0.6651_{* * *}^{* *}$ & 0.2776 & $0.2249_{*}$ & 0.2129 \\
\hline D1982 & 0.5840 & 0.6707 & $1.1754^{* * *}$ & 0.3807 & $0.7191^{* * *}$ & 0.2604 \\
\hline D1983 & $1.1842^{* *}$ & 0.589 & $1.6626^{* * *}$ & 0.3616 & $1.0098^{* * *}$ & 0.2693 \\
\hline D1984 & $1.3077^{* *}$ & 0.5521 & $1.5298^{* * *}$ & 0.3160 & $0.943^{* * *}$ & 0.2269 \\
\hline D1985 & $2.5141_{* * *}^{* * *}$ & 0.8542 & $1.6257_{* * * *}^{* * *}$ & 0.5028 & $0.7304^{* *}$ & 0.3366 \\
\hline D1986 & $1.9906^{* *}$ & 0.8213 & $1.5619^{* * *}$ & 0.4861 & 0.3883 & 0.3275 \\
\hline D1987 & $1.5997^{*}$ & 0.8196 & $1.3547^{* * *}$ & 0.4844 & 0.0441 & 0.3194 \\
\hline D1988 & 1.1596 & 0.8539 & $1.7641_{* * *}^{* * *}$ & 0.4918 & -0.121 & 0.3215 \\
\hline D1989 & 1.2600 & 0.8478 & $1.4852_{* * *}^{* * *}$ & 0.4897 & -0.3445 & 0.3344 \\
\hline D1990 & 0.9941 & 0.816 & $1.2728^{* * *}$ & 0.4857 & -0.0473 & 0.3305 \\
\hline D1991 & 1.1388 & 0.8663 & $1.2185^{* *}$ & 0.5269 & -0.2339 & 0.3560 \\
\hline D1992 & -0.0701 & 0.9301 & 0.7545 & 0.5791 & $-0.6926_{* *}^{*}$ & 0.3866 \\
\hline D1993 & -0.8230 & 1.0129 & 0.1191 & 0.5917 & $-1.3155_{* * * *}^{* * *}$ & 0.3986 \\
\hline D1994 & -0.3681 & 1.0456 & -1.0036 & 0.7071 & $-1.5539_{* * *}^{* *}$ & 0.4225 \\
\hline D1995 & -0.6469 & 0.9911 & 0.8499 & 0.5465 & $-1.1373^{* * *}$ & 0.3682 \\
\hline D1996 & 0.2008 & 0.917 & $0.8964^{*}$ & 0.5236 & -0.2966 & 0.3334 \\
\hline D1997 & -0.3814 & 0.9494 & $0.4424_{* *}$ & 0.5309 & -0.4046 & 0.3338 \\
\hline D1998 & 1.1804 & 0.9596 & $1.2123^{* *}$ & 0.5358 & $-0.5761^{*}$ & 0.3498 \\
\hline Num. Obs. & 1,316 & & 4713 & & 44,688 & \\
\hline Adjusted $\mathrm{R}^{2}$ & 0.2287 & & 0.1382 & & 0.1017 & \\
\hline
\end{tabular}

* Significant at the $10 \%$ level

** Significant at the 5\% level

Significant at the $1 \%$ level

The adjusted $\mathrm{R}^{2}$ for the logit equations measures the proportion of the log-likelihood value explained by the model's non-intercept independent variables, i.e., 1 - $\left(\right.$ log $\left.\mathrm{L}_{\mathrm{AL}}\right) /$ $\left(\log \mathrm{L}_{\mathrm{INT}}\right.$ ), where $\mathrm{L}_{\mathrm{ALL}}$ denotes the likelihood value of estimation with all the independent variables and $\mathrm{L}_{\mathrm{INT}}$ denotes the likelihood value of estimation with only the intercept. 


\begin{tabular}{|c|c|c|c|c|c|c|}
\hline \multirow[b]{2}{*}{ Variable } & \multicolumn{2}{|c|}{$\begin{array}{l}\text { Large Metropolitan } \\
\text { Markets }\end{array}$} & \multicolumn{2}{|c|}{$\begin{array}{l}\text { Small Metropolitan } \\
\text { Markets }\end{array}$} & \multicolumn{2}{|c|}{$\begin{array}{l}\text { Rural } \\
\text { Markets }\end{array}$} \\
\hline & Parameter Estimate & Standard Error & Parameter Estimate & Standard Error & Parameter Estimate & Standard Error \\
\hline INTERCEPT & $-12.8178^{*}$ & 7.1394 & $-10.0232^{* *}$ & 4.4075 & $-20.5065_{* * * *}^{* * *}$ & 3.0758 \\
\hline MKT-MERGE & 0.3227 & 1.0901 & $1.7028_{* *}^{*}$ & 0.8698 & $2.1331_{* * *}^{* * *}$ & 0.7082 \\
\hline MKT-ACQUIS & 7.1788 & 4.4002 & $4.4142_{* *}^{* *}$ & 1.9450 & $2.5724^{*}$ & 1.3292 \\
\hline MKT-HERF & 2.7694 & 3.2458 & $-4.4246^{* *}$ & 1.8049 & 0.0290 & 0.8511 \\
\hline MKT-SHAREL & -5.4667 & 4.9950 & 0.9364 & 1.4665 & $-0.6667 *$ & 0.5703 \\
\hline MKT-SHAREM & -3.4495 & 6.3984 & 0.2549 & 1.4420 & $0.7596^{*}$ & 0.3993 \\
\hline MKT-SHAREC & 0.8781 & 0.6562 & 0.6710 & 0.4349 & 0.3447 * & 0.3330 \\
\hline LIMITB & -0.4336 & 0.4994 & 0.1259 & 0.2643 & $0.7341^{* * *}$ & 0.1821 \\
\hline MKT-GROW & $-1.0356_{*}$ & 0.8389 & -0.4120 & 0.5236 & -0.6434 & 0.5075 \\
\hline STINCOME & $23.2561^{*}$ & 12.5409 & 3.2218 & 6.5365 & -1.8830 & 4.6638 \\
\hline MKT-PFRAT & $-1.8493_{* * *}$ & 2.9613 & $-1.1301_{* *}$ & 1.8827 & $-0.6910_{* * *}$ & 1.6644 \\
\hline MKT-LNDEP & $1.1507^{* * *}$ & 0.2668 & $0.6248^{* *}$ & 0.2449 & $1.1956^{* * *}$ & 0.2440 \\
\hline MKT-MDEP2 & & & 0.2850 & 0.3434 & & \\
\hline MKT-RDEP2 & & & & & -0.3964 & 0.4002 \\
\hline MKT-RDEP3 & & & & & -0.4411 & 0.5679 \\
\hline MKT-P1 & 6.3482 & 8.3047 & -1.2652 & 5.3978 & 5.2187 & 3.2473 \\
\hline MKT-P2 & -5.1524 & 9.3966 & 3.5418 & 4.0489 & 0.4736 & 2.6579 \\
\hline MKT-P3 & $-55.6001^{*}$ & 28.6133 & $3.9843_{* *}$ & 15.2674 & -2.3937 & 8.0891 \\
\hline MKT-P4 & -21.3150 & 33.5434 & $-30.7585^{* *}$ & 15.3177 & 8.7144 & 15.0744 \\
\hline MKT-W1 & -36.5973 & 39.6541 & 4.8075 & 23.0424 & 10.7385 & 14.6081 \\
\hline MKT-W2 & 17.7681 & 42.0028 & $77.3761^{* * *}$ & 26.2980 & $-30.4855^{*}$ & 17.8204 \\
\hline MKT-W3 & 0.0286 & 0.0395 & 0.0210 & 0.0277 & 0.0271 & 0.0200 \\
\hline
\end{tabular}


TABLE 4b (Continued)

\begin{tabular}{|c|c|c|c|c|c|c|}
\hline \multirow[b]{2}{*}{ Variable } & \multicolumn{2}{|c|}{$\begin{array}{l}\text { Large Metropolitan } \\
\text { Markets }\end{array}$} & \multicolumn{2}{|c|}{$\begin{array}{c}\text { Small Metropolitan } \\
\text { Markets }\end{array}$} & \multicolumn{2}{|c|}{$\begin{array}{l}\text { Rural } \\
\text { Markets }\end{array}$} \\
\hline & Parameter Estimate & Standard Error & Parameter Estimate & Standard Error & Parameter Estimate & Standard Error \\
\hline MKT-ROE & $9.5023^{*}$ & 5.6274 & 0.6082 & 1.2376 & 0.0274 & 2.7227 \\
\hline MKT-NPL & $-60.0671^{* * *}$ & 29.8173 & $-46.0577^{* *}$ & 18.2374 & -0.6843 & 8.7637 \\
\hline MKT-EQRAT & -10.2621 & 21.4244 & $-24.1610^{* *}$ & 11.6090 & -4.9476 & 6.8401 \\
\hline MKT-EFFIC & -0.9550 & 2.2221 & $-3.5840^{* * *}$ & 1.1931 & -1.6461 & 1.0393 \\
\hline D1996 & $1.5414^{* *}$ & 0.7203 & -0.5471 & 0.4704 & $0.6413^{*}$ & 0.3406 \\
\hline D1997 & 1.1365 & 0.9138 & -0.4396 & 0.5605 & $0.9611^{* *}$ & 0.3848 \\
\hline D1998 & $2.6543^{* * *}$ & 0.657 & -0.0734 & 0.4218 & 0.2797 & 0.3357 \\
\hline Num. Obs. & 303 & & 969 & & 9,407 & \\
\hline Adjusted $\mathrm{R}^{2}$ & 0.2150 & & 0.0898 & & 0.1299 & \\
\hline
\end{tabular}

* Significant at the $10 \%$ level
** Significant at the $5 \%$ level

*** Significant at the $5 \%$ level

The adjusted $\mathrm{R}^{2}$ for the logit equations measures the proportion of the log-likelihood value explained by the model's non-intercept independent variables, i.e., 1 - (log $\left.\mathrm{L}_{\mathrm{ALL}}\right)$ / $\left(\log \mathrm{L}_{\mathrm{INT}}\right)$, where $\mathrm{L}_{\mathrm{ALL}}$ denotes the likelihood value of estimation with all the independent variables and $\mathrm{L}_{\mathrm{INT}}$ denotes the likelihood value of estimation with only the intercept. Some missing or unusual coefficients and standard errors appear for some of the state banking regulation variables for the 1995-1998 subperiod because most of the deregulation occurred prior to 1995.UNITB, NEWLIB, and INTST are excluded from these regressions because there was little or no variation in these regulatory rules during this subperiod. 
banks with bank types coded as subject to special analysis, such as bankers' banks, credit card banks with commercial bank charters, depository trust companies, and bridge entities. The means and standard deviations in table 3 also reflect these exclusions. We further restrict the definition of entry in a robustness check discussed later.

\section{A. The Effects of M\&As on Subsequent Entry}

The data are strongly consistent with the hypothesis that M\&As are associated with subsequent increases in the probability of entry into the markets in which the M\&As occur. For the full 1980-1998 data set shown in table $4 \mathrm{a}$, the coefficients on the proportions of market deposits involved in recent bank mergers (MKT-MERGE) and in BHC acquisitions (MKT-ACQUIS) are positive and statistically significant in all three types of markets (large metropolitan, small metropolitan, and rural); four of the six parameters are significant at the $1 \%$ level, one is significant at the $5 \%$ level, and one is significant at the $10 \%$ level. ${ }^{10}$ For the 1995-1998 subperiod shown in table $4 \mathrm{~b}$, the coefficients of MKT-MERGE and MKT-ACQUIS remain positive in all cases, but the degree of statistical significance is less. One of the six parameters is significant at the $1 \%$ level, one is significant at the $5 \%$ level, two are significant at the $10 \%$ level. The drop in significance from the full sample to the 1995-1998 subsample is not surprising, given that most of the observations are excluded. In addition, there is less variance in most of the economic conditions specified in the exogenous variable list during the subperiod, which makes accurate estimation more difficult.

The results of these logit equations also suggest that M\&As have an economically significant impact as well as a statistically significant impact on the probability of de novo entry. We summarize the economic impact by estimating the predicted decrease in entry probability from reducing M\&A activity. For the full 1980-1998 data set for large metropolitan markets, reducing MKT-MERGE and MKTACQUIS from their mean values of 0.181 and 0.035 , respectively, to zero (multiplied by the corresponding coefficients from the first column of table $4 \mathrm{a}$ of 0.9936 and 4.1309 , respectively) implies a decrease in the predicted probability of de novo entry from its actual mean of $48.9 \%$ to $40.9 \% .{ }^{11}$ This is a decrease of 8.0 percentage points

10. The coefficients for MKT-MERGE and MKT-ACQUIS are significantly different from each other at the $10 \%$ level for the large metropolitan markets but not for other markets.

11. We base the economic significance evaluations on the sample mean value of the data used in the logit equations of $48.9 \%$, as shown in table 3 , rather than the slightly different mean of $51.32 \%$ shown earlier. As noted previously, the data used in the logit equations exclude some observations with missing or unreliable values of some of the variables and large or unusual types of de novo entries. 
or $16.4 \% .{ }^{12}$ An alternative summary statistic for the effects of M\&As is to measure the consequence of the change from the 75th to the 25th percentiles of the distributions of the M\&A variables, as in Rajan and Zingales (1998). For the large metropolitan markets, this implies a decrease in the predicted probability of entry from $52.9 \%$ to $42.2 \%$, a decline of 10.7 percentage points or a $20.2 \%$ decrease. For small metropolitan markets, moving from the means of the M\&A variables to zero reduces the mean predicted probability from $14.2 \%$ to $12.8 \%$, a decline of 1.4 percentage points or $9.9 \%$; and the change from the 75th to the 25 th percentiles yields a decrease in the probability of entry from $16.0 \%$ to $12.8 \%$, a decline of 3.2 percentage points or $20.0 \%$. For rural markets, moving from the means to zero or from the 75th to the 25th percentiles gives the same reduction in predicted probability of entry from $1.8 \%$ to $1.6 \%$, an $11.1 \%$ decrease. Therefore, approximating the effects of M\&As by moving from the means of the M\&A variables to zero or from the 75 th to the 25 th percentiles reduces the proportion of the markets with entry by about $10-20 \%$, which is economically significant.

The estimated parameters for the M\&A variables in the logit equations using the 1995-1998 subsample shown in table $4 \mathrm{~b}$ are larger than those for the full sample in five of six cases, and there is more M\&A activity in this subperiod. Therefore, the data from this subperiod imply greater estimated economic significance, although with reduced statistical significance. Overall, the logit regressions suggest a strong, statistically significant and economically significant effect of M\&As on subsequent entry, especially in metropolitan markets.

\section{B. Robustness of the Findings}

To assure confidence in our main findings, we run three sets of robustness checks. The first set keeps the exogenous variables and data samples the same as in the main runs but uses alternative econometric methods to the logit model of entry. The second set uses the main econometric specifications and data samples but alters the specifications of the exogenous variables. The third set uses the main econometric specification and exogenous variables but alters the data samples. To save space, the robustness results are summarized here but not shown in the tables.

The following alternative econometric specifications were tried: ordinary least squares, or OLS (i.e., a linear probability model of entry

12. Beginning at the mean probability of entry of 0.489 , the effect of decreasing MKTMERGE by 0.181 and MKT-ACQUIS by 0.035 is calculated as decreasing the probability of entry to $P_{1}$ in the formula $\ln \left[P_{1} /\left(1-P_{1}\right)\right]=\ln [0.489 /(1-0.489)]-(0.9936 \cdot 0.181)-$ $(4.1309 \cdot 0.035)$. 
versus no entry); Tobit (in which the number of entries in each market in each year is the dependent variable); OLS in which the number of entries was the dependent variable; OLS in which the dependent variable was 1 plus the log of the number of entries; and ordered logits for various categorizations of the multiple numbers of entry per market. The coefficients on the M\&A (MKT-MERGE and MKTACQUIS) variables remained positive and significant in almost all instances. We also employed a more complete fixed-effects approach with dummy variables for individual markets to allow for the possibility that the markets have important characteristics that make them attractive both to M\&As and entry that are not captured by our explanatory variables. ${ }^{13}$ For the complete sample, all six M\&A coefficients remain positive, although with reduced levels of statistical and economic significance. ${ }^{14}$ For the 1995-1998 subperiod, five of the six M\&A variables remain positive.

Turning next to our robustness checks that use alternative specifications of the exogenous variables, we tried the following variations of the exogenous variables: distinguishing between in-market versus market-extension mergers; distinguishing between mergers in which the pro forma consolidated bank is small versus large; distinguishing between mergers of affiliates of a holding company versus mergers of previously unaffiliated banks; specifying the individual $t-1, t-2$, and $t-3$ lags of the main M\&A variables instead of the 3 -year averages; adding lags to the variable that represents a state's change to a more liberal branching regime (NEWLIB); and adding second-order terms on the continuous exogenous variables to allow for nonlinearities (e.g., 1/2 MKT-HERF ${ }^{2}$ ). Again, our main results emerge: The coefficients on the M\&A variables generally remain positive and economically significant, with some weakening of statistical significance.

We finally turn to our robustness checks that alter the data samples. First, we include thrift entry as well as commercial bank entry in the dependent variable, similar to Seelig and Critchfield (2002). Our results for this data modification are even stronger than our main results just reported. When we include thrift entry we find that, for the full sample, all six coefficients of the M\&A variables are positive

13. This approach was complicated by the large number of markets in our sample. For the large metropolitan markets, we were able to estimate our basic logit regressions with 83 market dummy variables included. For the small metropolitan and rural regressions, the numbers of markets were too large. Instead, a linear probability approach (OLS) was used with all variable values subtracted from their respective market means. This yields slope coefficients identical to those that would be yielded by the inclusion of a complete set of market dummy variables.

14. For example, for the large metropolitan markets, moving from the means of the M\&A variables to zero would imply a reduction in entry to a mean level of $43.0 \%$ (from $48.9 \%$ ), a reduction of 6.9 percentage points or $12.1 \%$. 
and statistically significant at the 1\% level; and for the 1995-1998 subsample, all six are positive and five of the six are statistically significant at some level. The coefficients are also of the same order of magnitude as in the main results. We further restricted the data sample to the years 1995-1997 (similar to Seelig and Critchfield's original paper). Four of the six M\&A variables remain positive and statistically significant. Next, we employed a more conservative definition of the dependent variable, in which we counted as an "entrant" only a bank that had less than $\$ 100$ million in assets at the end of its first year, had an equity ratio of at least $20 \%$, and was involved in no M\&A activity itself. Using this restricted dependent variable, the six coefficients on the M\&A variables remained positive and with approximately the same levels of economic significance, although only two of the six coefficients attain significance (at the $1 \%$ level).

In sum, our statistically and economically significant positive relationship between M\&As and the probability of de novo entry is quite robust. The alternative econometric methods, alternative exogenous variable specifications, and alternative data samples all support our main results.

\section{The Effects of Variables Other than M\&As on Entry}

The estimated coefficients on the variables other than M\&As in tables $4 \mathrm{a}$ and $4 \mathrm{~b}$ are mostly consistent with the hypotheses given earlier, although they are often not statistically significant. We hypothesized that market profits, market growth in deposits, and related variables like the purchased funds ratio and the growth of state income should have positive effects on expected future profitability and the likelihood of de novo entry. The coefficients of the profitability variable MKT-ROE in tables $4 \mathrm{a}$ and $4 \mathrm{~b}$ are mixed-positive for the metropolitan markets but negative for the rural markets - giving no clear effect of profitability on the likelihood of entry, after M\&As and all the other factors are controlled for in the regressions. The coefficients of MKT-GROW are always negative but not statistically significant, but the coefficients of MKT-PFRAT and STGROW are all positive and statistically significant for the full data sample, giving support for the importance of some of the factors that are similar to growth but not supporting the growth of the market itself as predicting more entry after controlling for these other factors.

We also predicted that concentration may have a positive effect on the probability of entry if it proxies mostly profit opportunities from market power and a negative impact if it proxies mostly high entry barriers. The coefficients of MKT-HERF are of mixed signs and mostly not statistically significant, giving no evidence that either effect dominates. 
We hypothesized that state banking regulations that create barriers to entry by incumbent firms from other markets may increase the probability of entry. The coefficients of UNITB are positive, statistically significant, and larger than the LIMITB coefficients for the full time period, consistent with the hypothesis. The coefficients of LIMITB are positive and significant for rural markets in both time periods, also consistent with the hypothesis. However, the LIMITB coefficients have mixed signs for the metropolitan markets, presumably because limited branching laws typically allow unlimited branching within counties and mostly keep large banks based in metropolitan counties from branching elsewhere. States with newly liberalized branching rules (NEWLIB) have positive coefficients, suggesting that part or all of the effect of moving from unit or limited to statewide branching status or from limited to statewide branching is offset in the initial year. ${ }^{15}$ Interstate BHC access (INTST), which has an ambiguous predicted effect, has mixed coefficients.

As discussed, the probability of entry may be positively or negatively related to output prices, depending on whether high rates proxy more for profitable opportunities (positive) versus high default risks (negative). The results are somewhat mixed, with the prices of consumer loans (P1) and non-real-estate business loans (P2) generally being positively related to the probability of entry and the price of real estate loans (P3) being negatively and statistically significantly related to the probability of entry for the full sample. These results suggest that while market power in pricing loans may encourage entry in some cases, a high price of real estate loans more likely signals high default probabilities in the market, which may deter future bank entry. The input prices (W1, W2, W3) generally have the negative hypothesized signs for the full sample.

We hypothesized that greater market shares of large or organizationally complex banks increase the probability of entry, but the data are only half consistent with this. The regressions in tables $4 \mathrm{a}$ and $4 \mathrm{~b}$ suggest that a greater presence of larger banks (SHAREL or SHAREM) discourages entry, contrary to expectations, while a greater presence of complexly organized banks (owned by out-of-state or multilayered $\mathrm{BHCs}$ ) encourages entry, consistent with expectations.

We hypothesized that more efficient or financially sound incumbents may be stronger competitors and deter entry. Again, the data are mixed. High equity capital (MKT-EQRAT) is associated with less entry in small metropolitan and rural markets, as predicted, and the coefficients of efficiency (MKT-EFFIC) are usually negative, as predicted. But the coefficients of nonperforming loans (MKT-NPL) are

15. Two additional lagged values for NEWLIB were tried but were not statistically significant and had no material effect on the results. 
generally negative, contrary to the prediction. As noted, it is also possible that better-performing incumbents in a market is a proxy for favorable market conditions that encourage entry, which may explain the latter results.

Further, we hypothesized that larger markets and metropolitan markets would have more entry. Our main controls for these are in setting up the separate regressions for the large metropolitan, small metropolitan, and rural data subsets. Within these regressions, the log of market deposits (MKT-LNDEP) always has a positive, statistically significant coefficient, consistent with expectations. The additional size class dummies have insignificant coefficients, suggesting that our division of the data into subsets plus including MKT-LNDEP was sufficient to account for most of the effects of market size.

Finally, the magnitudes and statistical significance of the coefficients on our annual dummy variables track the general pattern of entry shown in table 2, rising during most of the 1980s, declining in the late 1980s and early 1990s, and recovering somewhat in the late 1990s. This pattern is generally consistent with the positive effects of the OCC charter liberalization and unit banking restrictions in the early and mid-1980s, the deterioration in banking conditions in the late 1980 s to early 1990 s, and the recovery in banking conditions at the end of the sample period. Importantly, our main results concerning the effects of M\&As on entry are robust and relatively unaffected by the presence or absence of the annual dummy variables, suggesting that our main results about the effects of M\&As are in addition to these overall temporal patterns.

Overall, the results are strongly consistent with the positive effects of M\&As and market size, although most of the other hypotheses receive only mixed support.

\section{Conclusions}

We study the dynamics of market entry following mergers and acquisitions. Our empirical application focuses on the commercial banking industry, which provides a superior laboratory for analyzing these effects, because banks produce relatively homogeneous products in a large number of geographically segmented markets under different conditions. We are able to trace the effects of over 10,000 M\&As in over 2,700 local banking markets during a period of 19 years, with over 52,000 market-year observations, and almost 4,000 actual market entries.

Our findings are strongly consistent with the hypothesis that M\&As are associated with subsequent increases in the probability of entry into the markets in which the M\&As occur. The results are both statistically and economically significant. Our approximation of the 
effects of M\&As by moving from the means of the M\&A variables to zero or from the 75 th to the 25 th percentiles reduces the proportion of the markets with entry by about $10-20 \%$ of all entry, which is economically significant. We also run three sets of robustness checks that (1) use alternative econometric methods, (2) change the specifications of the exogenous variables, and (3) alter the data samples. These findings support our main result that M\&As tend to increase the probability of subsequent de novo entry.

The findings also have implications for policy and future research. With respect to policy, the result that the probability of entry increases substantially after local market M\&As tends to support a continued role for prospective entry in antitrust analysis. The findings are also consistent with an external effect of consolidation in which any reduction in small business lending by M\&A participants may be partially replaced by new entrants.

With respect to future research, the findings suggest that M\&As and possibly other actions of incumbent firms should be included in future models of entry in both industrial organization and banking research. The results also suggest that effort be invested in evaluating a number of different external effects of M\&As on the behavior of other market participants beyond what has been considered here. In addition to entry and output, the responses of other firms in terms of their prices, locations, and product mix could be included in future industrial organization research. In banking research in particular, the external effects of M\&As on deposit and loan interest rates, quantities of other types of loans, geographical distributions of deposits, and quantity and location of bank branches could be further studied.

\section{References}

Amel, D. F., and J. N. Liang. 1997. Determinants of entry and profits in local banking markets. Review of Industrial Organization 12 (February):59-78.

Avery, R. B., and K. A. Samolyk. 2004. Bank consolidation and the provision of banking services: Small commercial loans. Journal of Financial Services Research 25 (April/June): 291-325.

Bain, J. S. 1956. Barriers to new competition. Cambridge, MA: Harvard University Press.

Baldwin, J., and P. Gorecki. 1991. Firm entry and exit in Canadian manufacturing sector. Canadian Journal of Economics 24 (May):300-23.

Berger, A. N., R. S. Demsetz, and P. E. Strahan. 1999. The consolidation of the financial services industry: Causes, consequences, and implications for the future. Journal of Banking and Finance 23 (February):135-94.

Berger, A. N., L. G. Goldberg, and L. J. White. 2001. The effects of dynamic changes in bank competition on the supply of small business credit. European Finance Review 5 (January):115-39.

Berger, A. N., A. K. Kashyap, and J. M. Scalise. 1995. The transformation of the U.S. banking industry: What a long, strange trip it's been. Brookings Papers on Economic Activity 2:155-218.

Berger, A. N., A. Saunders, J. M. Scalise, and G. F. Udell. 1998. The effects of bank mergers and acquisitions on small business lending. Journal of Financial Economics 50 (November): $187-229$. 
Chappel, W. F., M. S. Kimenyi, and W. J. Mayer. 1990. A Poisson probability model of entry and market structure with an application to U.S. industries during 1972-77. Southern Economic Journal 56:918-27.

Cornett, M., and H. Tehranian. 1992. Changes in corporate performance associated with bank acquisitions. Journal of Financial Economics 31 (April):211-34.

Epstein, J. D. 1996. Years of bank mergers trigger a rise in startups looking for their niche. American Banker (December 27):1, 6.

Geroski, P. A. 1995. What do we know about entry? International Journal of Industrial Organization 13, no. 4 (December):421-40.

Joskow, A. S., G. J. Werden, and R. L. Johnson. 1994. Entry, exit, and performance in airline markets. International Journal of Industrial Organization 12 (December):457-71.

Keeton, W. R. 2000. Are mergers responsible for the surge in new bank charters? Federal Reserve Bank of Kansas City Economic Review 85 (Q1): 21-41.

Kim, W., and L. J. White. 2001. The impact of mergers on U.S. bank performance. In: Economic Theory, Dynamics and Markets: Essays in Honor of Ryuzo Sato, ed. T. Negishi, R. Ramachandran, and K. Mino.Boston: Kluwer Academic Publishers.

Kwan, S. 1998. Bank charters vs. thrift charters. Federal Reserve Bank of San Francisco Weekly Letter, no. 98-13 (April 24).

Kwast, M. L., M. Starr-McCluer, and J. Wolken. 1997. Market definition and the analysis of antitrust in banking. Antitrust Bulletin, 42 (Winter):973-95.

Mata, J. 1993. Entry and type of entrant: Evidence from Portugal. International Journal of Industrial Organization 11 (March):101-22.

Moore, R. R., and E. C. Skelton. 1998. New banks: Why enter when others exit? Financial Industry, Federal Reserve Bank of Dallas, (Q1):1-6.

Morch von der Fehr, N.-H. 1991. Domestic entry in Norwegian manufacturing industries. In: Entry and Market Contestability, ed. P. A. Geroski and J. Schwalbach. Oxford: Basil Blackwell, pp. 89-110.

Orr, D. 1974. The determinants of entry: A study of the Canadian manufacturing industries. Review of Economics and Statistics 56 (February):58-65.

Rajan, R. G., and L. Zingales. 1998. Financial dependence and growth. American Economic Review 88 (June):559-86.

Rhoades, S. A. 1997. Have barriers to entry in retail commercial banking disappeared? Antitrust Bulletin 42 (Winter):997-1013.

Seelig, S. A., and T. Critchfield. 2002. Merger activity as a determinants of de novo entry into urban bank markets. Working Paper 1999-1, Federal Deposit Insurance Corporation, updated June 2002.

Siegfried, J. J., and L. B. Evans. 1992. Entry and exit in United States manufacturing industries from 1977 to 1982. In: Empirical Studies in Industrial Organization: Essays in Honor of Leonard W. Weiss, ed. D. W. Audretsch and J. J. Siegfried. Dordrecht, the Netherlands: Kluwer Academic Publishers, pp. 253-73.

Siegfried, J. J., and L. B. Evans. 1994. Empirical studies of entry and exit: A survey of the evidence. Review of Industrial Organization 9 (April):121-55.

Stein J. C. 2002. Information Production and Capital Allocation: Decentralized vs. Hierarchical Firms. Journal of Finance 57 (October):1891-1921.

Sylos-Labini, Paolo. 1962. Oligopoly and technical progress. Cambridge, MA: Harvard University Press.

Toevs, A. 1992. Under what circumstances do bank mergers improve efficiency? Proceedings of a conference on Bank Structure and Competition, Federal Reserve Bank of Chicago, Chicago, pp. 602-28.

Werden, G. J., and L. M. Froeb. 1998. The entry-inducing effects of horizontal mergers: An explanatory analysis. Journal of Industrial Economics 46 (December):525-43.

White, E. N. 1992. The comptroller and the transformation of American banking, 19601990. Washington, DC: Office of the Comptroller of the Currency. 
Copyright of Journal of Business is the property of University of Chicago Press and its content may not be copied or emailed to multiple sites or posted to a listserv without the copyright holder's express written permission. However, users may print, download, or email articles for individual use. 